Veith, M., Mayer, C., Samraoui, B., Donaire Barroso, D., Bogaerts, S., 2004. From Europe to Africa and viceversa: evidence for multiple intercontinental dispersal in ribbed salamanders (Genus Pleurodeles). J. Biogeogr. 31, 159-171.

Vences, M., Vieites, D.R., Glaw, F., Brinkmann, H., Kosuch, J., Veith, M., Meyer, A. 2003. Multiple overseas dispersal in amphibians. Proc. Roy. Soc. London B 270 , $2435-2442$.

Voelker, G., 1999. Dispersal, vicariance, and clocks: historical biogeography and speciation in a cosmopolitan passerine genus (Anthus: Motacillidae). Evolution $53,1536-1552$.

Waltari, E., Hijmans, R.J., Peterson, A.T., Nyári, Á.S., Perkins, S.L., Guralnick, R.P., 2007. Locating pleistocene refugia: comparing phylogeographic and ecological niche model predictions. PLoS ONE 2, e563.

Wan, S., Li, A., Clift, P.D., 2007. Development of the East Asian monsoon: mineralogical and Sedimentologic records in the northern South China Sea since 20 Ma. Palaeogeogr. Palaeoclimat. Palaeoecol. 254, 561-582.

Wiens, J.J., 2000. Reconstructing phylogenies from allozyme data: comparing method performance with congruence. Biol. J. Linn. Soc. 70, 613-632.
Williams, S.E., Bolitho, E.E., Fox, S., 2003. Climate change in Australian tropical rainforests: an impending environmental catastrophe. Proc. Roy. Soc. Lond. B. Biol. 270, 1887-1892.

Zajc, I., Arntzen, J.W., 1999. Phylogenetic relationships of the European newts (genus Triturus) tested with mitochondrial DNA sequence data. Contr. Zool. 68, 73-81.

Zangari, F., Cimmaruta, R., Nascetti, G., 2006. Genetic relationships of the western Mediterranean painted frogs based on allozymes and mitochondrial markers: evolutionary and taxonomic inferences (Amphibia, Anura, Discoglossidae). Biol. J. Linnean Soc. 87, 515-536.

Zeisset, I., Beebee, T.J.C., 2008. Amphibian phylogeography: a model for understanding historical aspects of species distributions. Heredity 101,109-119.

Zhan, A., Fu, J., 2011. Past and present: phylogeography of the Bufo gargarizans species complex inferred from multi-loci allele sequence and frequency data. Mol. Phylogenet. Evol. 61, 136-148.

Zheng, Y., Fu, J., Li, S., 2009. Toward understanding the distribution of Laurasian frogs: a test of Savage's biogeographical hypothesis using the genus Bombina. Mol. Phylogenet. Evol. 52, 70-83. 
Kozak, K.H., Graham, C.H., Wiens, J.J., 2008. Integrating GIS-based environmental data into evolutionary biology. Trends Ecol. Evol. 23, 141-148.

Kutrup, B., Yilmaz, N., Canakci, S., Belduz, A.O., Doglio, S., 2006. Intraspecific variation of Bufo bufo, based on $16 \mathrm{~S}$ ribosomal RNA sequences. AmphibiaReptilia 27, 268-273.

Litvinchuk, S.N., Borkin, L.J., Skorinov, D.V., Rosanov, J.M., 2008. A new species of common toads from the Talysh Mountains, south-eastern Caucasus: genome size, allozyme, and morphological evidences. Russ. J. Herpetol. 15, 19-43.

Liu, L., Eronen, J.T., Fortelius, M., 2009. Significant mid-latitude aridity in the middle Miocene of East Asia. Palaeogeogr. Palaeoclimat. Palaeoecol. 279, 201-206.

Lizana, M., 2002. Bufo bufo (Linnaeus, 1758). Sapo común, escuerzo. In: Pleguezuelos, J.M., Marquez, R., Lizana, M. (Eds.), Atlas y libro rojo de los anfibios y reptiles de España. De Medio Ambiente, Madrid, pp. 103-108.

Llorente, G.A., Montori, A., Santos, X., Carretero, M.A., 1995. Atlas dels amfibis i rèptils de Catalunya i Andorra. Ed. El Brau, Barcelona.

Ma, Y.Z. Li, J.J., Fang, X.M., 1998. Pollen assemblage in 30.6-5.0 Ma redbeds of Linxia region and climate evolution. Chin. Sci. Bull. 43, 301-304.

Maddison, W.P., Maddison, D.R., 2009. Mesquite: A Modular System for Evolutionary Analysis. Version 2.72. <http://mesquiteproject.org>.

Marshall, D.C., 2010. Cryptic failure of partitioned Bayesian phylogenetic analyses: lost in the land of long trees. Syst. Biol. 59, 108-117.

Martinez-Solano, I., Gonzalez, E.G., 2008. Patterns of gene flow and source-sink dynamics in high altitude populations of the common toad Bufo bufo (Anura: Bufonidae). Biol. J. Linnean Soc. 95, 824-839.

Mattoccia, M., Romano, A., Sbordoni, V., 2005. Mitochondrial DNA sequence analysis of the spectacled salamander, Salamandrina terdigitata (Urodela: Salamandridae), supports the existence of two distinct species. Zootaxa 995, $1-19$.

Measey, G.J., Vences, M., Drewes, R.C., Chiari, Y., Melo, M., Bourles, M., 2007. Freshwater paths across the ocean: molecular phylogeny of the frog Ptychadena newtoni gives insights into amphibian colonization of oceanic islands. J. Biogeogr. 34, 7-20.

Mein, P., 1999. European Miocene mammal biochronology. In: Rössner, G.E., Heissig, K. (Eds.), The Miocene Land Mammals of Europe. Verlag Dr. Friedrich Pfeil, Munich, pp. 25-38.

Melville, J., Hale, J., Mantziou, G., Ananjeva, N.B., Milto, K., Clemann, N., 2009. Historical biogeography, phylogenetic relationships and intraspecific diversity of agamid lizards in the Central Asian deserts of Kazakhstan and Uzbekistan. Mol. Phylogenet. Evol. 53, 99-112.

Mertens, R., Wermuth, H., 1960. Die Amphibien und Reptilien Europas. W. Kramer, Frankfurt am Main.

Molnar, P., Boos, W.R., Battisti, D.S., 2010. Orographic controls on climate and paleoclimate in Asia: thermal and mechanical roles for the Tibetan Plateau. Ann. Rev. Earth Planet. Sci. 38, 77-102.

Muratet, J., 2008. Identifier les Amphibiens de France metropolitaine. Association Ecodiv. Collection, Guide de terrain.

Nascetti, G., Zangari, F., Canestrelli, D., 2005. The spectacled salamanders, Salamandrina terdigitata (Lacépède, 1788) and S. perspicillata (Savi, 1821): genetic differentiation and evolutionary history. Rend. Fis. Acc. Lincei 16, 159-169.

Nei, M., 1978. Estimation of average heterozygosity and genetic distance from a small number of individuals. Proc. Natl. Acad. Sci. 70, 3321-3323.

Nogués-Bravo, D., 2009. Predicting the past distribution of species climatic niches. Glob. Ecol. Biogeogr. 18, 521-531.

Palo, J.U., Schmeller, D.S., Laurila, A., Primmer, C.R., Kuzmin, S.L., Merilä, J., 2004. High degree of population subdivision in a widespread amphibian. Mol. Ecol. $13,2631-2644$

Paulo, O.S., Dias, C., Bruford, M.W., Jordan, W.C., Nichols, R.A., 2001. The persistence of Pliocene populations through the Pleistocene climatic cycles: evidence from the phylogeography of an Iberian lizard. Proc. Roy. Soc. London B 268, 16251630.

Paulo, O.S., Pinheiro, J., Miraldo, A., Bruford, M.W., Jordan, W.C., Nichols, R.A., 2008. The role of vicariance vs dispersal in shaping genetic patterns in ocellated lizard species in the Western Mediterranean. Mol. Ecol. 17, 1535-1551.

Phillips, S.J., Dudík, M., 2008. Modeling of species distributions with Maxent: new extensions and a comprehensive evaluation. Ecography 31, 161-175.

Phillips, S.J., Anderson, R.P., Schapire, R.E., 2006. Maximum entropy modeling of species geographic distributions. Ecol. Model. 190, 231-259.

Pleguezuelos, J.M., Fahd, S., Carranza, S., 2008. El papel del Estrecho en la conformación de la actual fauna de anfibios y reptiles del Mediterráneo Occidental. Bol. Asoc. Herpetol. Españ. 19, 2-17.

Popov, S.V., Shcherba, I.G., Ilyina, L.B., Nevesskaya, L.A., Paramonova, N.P., KhondKarian, S.O., Magyar, I., 2006. Late Miocene to Pliocene palaeogeography of the Paratethys and its relation to the Mediterranean. Palaeogeogr. Palaeoclimat. Palaeoecol. 238, 91-106.

Posada, D., 2008. JModelTest: phylogenetic model averaging. Mol. Biol. Evol. 25, 1253-1256.

Pramuk, J.B., Robertson, T., Sites, J.W., Noonan, B.P., 2007. Around the world in 10 million years: biogeography of the nearly cosmopolitan true toads (Anura: Bufonidae). Glob. Ecol. Biogeogr. 17, 72-83.

Qiang, X., Li, Z., Powell, C., Zheng, H., 2001. Magnetostratigraphic record of the Late Miocene onset of the East Asian monsoon, and Pliocene uplift of northern Tibet. Earth Planet. Sci. Lett. 187, 83-93.

Rage, J.-C., Roček, Z., 2003. Evolution of anuran assemblages in the Tertiary and Quaternary of Europe, in the context of palaeoclimate and palaeogeography. Amphibia-Reptilia 24, 133-167.

Rambaut, A., Drummond, A.J., 2007. Tracer v1.4. <http://beast.bio.ed.ac.uk/Tracer>.
Randi, E., 2007. Phylogeography of South European mammals. In: Weiss, S., Ferrand, N. (Eds.), Phylogeography of Southern European Refugia. Springer, pp. 101-126.

Recuero, E., Iraola, A., Rubio, X., Machordom, A., Garcia-París, M., 2007. Mitochondrial differentiation and biogeography of Hyla meridionalis (Anura: Hylidae): an unusual phylogeographical pattern. J. Biogeogr. 34, 1207-1219.

Roelants, K., Bossuyt, F., 2005. Archaeobatrachian paraphyly and Pangaean diversification of crown-group frogs. Syst. Biol. 54, 111-126.

Roelants, K., Gower, D.J., Wilkinson, M., Loader, S.P., Biju, S.D., Guillaume, K., Moriau, L., Bossuyt, F., 2007. Global patterns of diversification in the history of modern amphibians. PNAS 104, 887-892.

Ronquist, F., Huelsenbeck, J.P., 2003. MrBayes 3: Bayesian phylogenetic inference under mixed models. Bioinformatics 19, 1572-1574.

Rowe, G., Harris, D.J., Beebee, T.J., 2006. Lusitania revisited: a phylogeographic analysis of the natterjack toad Bufo calamita across its entire biogeographical range. Mol. Phylogenet. Evol. 39, 335-346.

Saitou, N., Nei, M., 1987. The neighbor-joining method: a new method for reconstructing of phylogenetic trees. Mol. Biol. Evol. 4, 406-425.

Santucci, F., Nascetti, G., 1996. Hybrid zones between two genetically differentiated forms of the pond frog Rana lessonae in southern Italy. J. Evol. Biol. 9, 429-450.

Savage, J.M., 1973. The geographic distributions of frogs: patterns and predictions. In: Vial, J.L. (Ed.), Evolutionary Biology of Anurans. University of Missouri Press, Columbia, pp. 351-445.

Schmitt, T., 2007. Molecular biogeography of Europe: Pleistocene cycles and postglacial trends. Front. Zool. 4, 11.

Seddon, J.M., Santucci, F., Reeve, N.J., Hewitt, G.M., 2001. DNA footprints of European hedgehogs, Erinaceus europaeus and E. Concolor: Pleistocene refugia, postglacial expansion and colonization routes. Mol. Ecol. 10, 2187-2198.

Seppa, P., Laurila, A., 1999. Genetic structure of island populations of the anurans Rana temporaria and Bufo bufo. Heredity 82, 309-317.

Sexton, J.P., McIntyre, P.J., Angert, A.L., Rice, K.J., 2009. Evolution and ecology of species range limits. Ann. Rev. Ecol. Evol. Syst. 40, 415-436.

Shimodaira, H., 2002. An approximately unbiased test of phylogenetic tree selection. Syst. Biol. 51, 492

Shimodaira, H., Hasegawa, M., 2001. CONSEL: for assessing the confidence of phylogenetic tree selection. Bioinformatics 17, 1246-1247.

Solounias, N., Plavcan, J.M., Quade, J., Witmer, L., 1999. The paleoecology of the Pikermiam Biome and the sacanna myth. In: Agustí, J., Rook, L., Andrews, P. (Eds.), Evolution of Neogene Terrestrial Ecosystems in Europe. Cambridge University Press, pp. 436-453.

Soria-Carrasco, V., Castresana, J., 2011. Patterns of mammalian diversification in recent evolutionary times: global tendencies and methodological issues. J. Evol. Biol. 24, 2611-2623.

Stamatakis, A., 2006. RAxML-VI-HPC: maximum likelihood-based phylogenetic analyses with thousands of taxa and mixed models. Bioinformatics 22, 26882690.

Stewart, J., Lister, A., 2001. Cryptic northern refugia and the origins of the modern biota. Trends Ecol. Evol. 16, 608-613.

Stöck, M., Dubey, S., Klütsch, C., Litvinchuk, S.N., Scheidt, U., Perrin, N., 2008a. Mitochondrial and nuclear phylogeny of circum-Mediterranean tree frogs from the Hyla arborea group. Mol. Phylogenet. Evol. 49, 19-102.

Stöck, M., Sicilia, A., Belfiore, N.M., Buckley, D., Lo Brutto, S., Lo Valvo, M., Arculeo, M., 2008b. Post-Messinian evolutionary relationships across the Sicilian channel: mitochondrial and nuclear markers link a new green toad from Sicily to African relatives. BMC Evol. Biol. 8, 56

Sun, J., Ye, J., Wu, W., Ye, J., Wu, W., Ni, X., Bi, S., Zhang, Z., Liu, Z., Meng, J., 2010. Late oligocene-miocene mid-latitude aridification and wind patterns in the Asian interior. Geology 38, 515-518.

Sun, X., Wang, P., 2005. How old is the Asian monsoon system? Palaeobotanical records from China. Palaeogeogr. Palaeoclimat. Palaeoecol. 222, 181-222.

Svenning, J., Normand, S., Kageyama, M., 2008. Glacial refugia of temperate trees in Europe: insights from species distribution modeling. J. Ecol. 96, 1117-1127.

Swofford, D.L., Selander, R.B., 1981. BIOSYS-1. A Computer Program for the Analysis of Allelic Variation in Population Genetics and Biochemical Systematics. Illinois Nat. Hist. Survey, Champaigh.

Tamura, K., Peterson, D., Peterson, N., Stecher, G., Nei, M., Kumar, S., 2011. MEGA5: molecular evolutionary genetics analysis using maximum likelihood, evolutionary distance, and maximum parsimony methods. Mol. Biol. Evol. 28, 2731-2739.

Tarasov, P.E., Volkova, V.S., Webb III, T., Guiot, J., Andreev, A.A., Bezusko, L.G., Bezusko, T.V., Bykova, G.V., Dorofeyuk, N.I., Kvavadze, E.V., Osipova, I.M., Panova, N.K., Sevastyanov, D.V., 2000. Last glacial maximum biomes reconstructed from pollen and plant macrofossil data from northern Eurasia. J. Biogeogr. 27, 609-620.

Ursenbacher, S., Scheweiger, S., Tomovic, L., Crnobrnja-Isailovič, J., Fumagalli, L., Mayer, W., 2008. Molecular phylogeography of the nose-horned viper (Vipera ammodytes Linnaeus, 1758): evidence for high genetic diversity and multiple refugia in the Balkan Peninsula. Mol. Phylogenet. Evol. 46, 1116-1128.

Van Bocxlaer, I., Biju, S., Loader, S., Bossuyt, F., 2009. Toad radiation reveals intoIndia dispersal as a source of endemism in the Western Ghats-Sri Lanka biodiversity hotspot. BMC Evol. Biol. 9, 131

Van Bocxlaer, I., Loader, S.P., Roelants, K., Biju, S.D., Menegon, M., Bossuyt, F., 2010. Gradual adaptation toward a range-expansion phenotype initiated the global radiation of toads. Science 327, 679-682.

Van Dam, J.A., 2006. Geographic and temporal patterns in the late Neogene (12-3 Ma) aridification of Europe: the use of small mammals as paleoprecipitation proxies. Palaeogeogr. Palaeoclimat. Palaeoecol. 238, 190-218. 


\section{Appendix A. Supplementary material}

Supplementary data associated with this article can be found, in the online version, at doi:10.1016/j.ympev.2011.12.019.

\section{References}

Adams, J.M., Faure, H. (Eds.), 1997. QEN Members. Review and Atlas of Palaeovegetation: Preliminary Land Ecosystem Maps of the World since the Last Glacial Maximum. Oak Ridge National Laboratory, TN, USA. <http:// www.esd.ornl.gov/projects/qen/adams1.html>.

Agustí, J., Cabrera, L., Garces, M., Krijgsman, W., Oms, O., Pares, J.M., 2001. A calibrated mammal scale for the neogene of Western Europe. State of the art Earth-Sci. Rev. 52, 247-260.

Akın, C., Bilgin, M., Bilgin, C.C., 2010. Discordance between ventral colour and mtDNA haplotype in the water frog Rana (ridibunda) caralitana Arıkan, 1988. Amphibia-Reptilia 31, 9-20.

Azanza, B., Alberdi, M.T., Prado, J.L., 2000. Large mammal turnover pulses correlated with latest Neogene glacial trends in the northwestern Mediterranean region. Geol. Soc. London (Special Publications) 181, 161-170.

Babik, W., Branicki, W., Sandera, M., Litvinchuk, S., Borkin, L.J., Irwin, J.T., 2004 Mitochondrial phylogeography of the moor frog, Rana arvalis. Mol. Ecol. 13, $1469-1480$

Babik, W., Branicki, W., Crnobrnja-Isailovič, J., Cog, D., Lniceanu, A., Sas, I., Olgun, K., Poyarkov, N.A., Garcia-Paris, M., Artzen, J.W., 2007. Phylogeography of two European newt species-discordance between mtDNA and morphology. Mol. Ecol. 14, 2475-2491.

Báez, A.M., Nicoli, L., 2004. Bufonid toads from the Late Oligocene beds of Salla, Bolivia. J. Vertebr. Paleontol. 24, 73-79.

Benson, D.A., Karsch-Mizrachi, I., Lipman, D.J., Ostell, J., Wheeler, D.L., 2008 GenBank. Nucleic Acid Research 36 (Database issue), D25-30.

Biju, S.D., Bossuyt, F., 2003. New frog family from India reveals an ancient biogeographical link with the Seychelles. Nature 425, 711-714.

Blondel, J., Aronson, J., 1999. Biology and Wildlife of the Mediterranean Region. Oxford University Press, Oxford.

Borkin, L.J., 1984. The European-Far Eastern disjunctions in distribution of amphibians: a new analysis of the problem. Proc. Zool. Inst. Leningrad 124 55-88.

Brown, J.M., Hedtke, S.M., Lemmon, A.R., Lemmon, E.M., 2010. When trees grow too long: investigating the causes of highly inaccurate Bayesian branch-length estimates. Syst. Biol. 59, 145-161.

Buermann, W., Saatchi, S., Smith, T.B., Zutta, B.R., Chaves, J.A., Mila, B., Graham, C., 2008. Predicting species distributions across the Amazonian and Andean regions using remote sensing data. J. Biogeogr. 35, 1160-1176.

Canestrelli, D., Cimmaruta, R., Costantini, V., Nascetti, G., 2006. Genetic diversity and phylogeography of the Apennine yellow-bellied toad Bombina pachypus, with implications for conservation. Mol. Ecol. 15, 3741-3754.

Canestrelli, D., Verardi, A., Nascetti, G., 2007. Genetic differentiation and history of populations of the Italian treefrog Hyla intermedia: lack of concordance between mitochondrial and nuclear markers. Genetica 130, 241-255.

Carranza, S., Arnold, E.N., 2004. History of West Mediterranean newts, Pleurodeles (Amphibia: Salamandridae), inferred from old and recent DNA sequences. Syst. Biodivers. 1, 327-337.

Carranza, S., Wade, E., 2004. Taxonomic revision of Algero-Tunisian Pleurodeles (Caudata: Salamandridae) using molecular and morphological data. Revalidation of the taxon Pleurodeles nebulosus (Guichenot, 1850). Zootaxa $488,1-24$.

Carranza, S., Arnold, E.N., Pleguezuelos, J.M., 2006. Mitochondrial DNA indicates the Mediterranean snakes, Malpolon monspessulanus and Hemorrhois hippocrepis (Squamata, Colubridae), are recent colonizers of the Iberian Peninsula. Mol. Phylogenet. Evol. 40, 532-546.

Carranza, S., Arnold, E.N., Wade, E., Fahd, S., 2004. Phylogeography of the false smooth snakes, Macroprotodon (Serpentes, Colubridae): mitochondrial DNA sequences show European populations arrived recently from Northwest Africa. Mol. Phylogenet. Evol. 33, 523-532.

Castresana, J., 2000. Selection of conserved blocks from multiple alignments for their use in phylogenetic analysis. Mol. Biol. Evol. 17, 540-552.

Cosson, J.F., Hutterer, R., Libois, R., Sara, M., Taberlet, P., Vogel, P., 2005 Phylogeographical footprints of the strait of Gibraltar and quaternary climatic fluctuations in the western Mediterranean: a case study with the greater whitetoothed shrew, Crocidura russula (Mammalia: Soricidae). Mol. Ecol. 14, 11511162.

Crochet, P.A., Dubois, A., 2004. Recent changes in the taxonomy of European amphibians and reptiles. In: Gasc, J.P., Cabela, A., Crnobrnja-Isailovic, J., Dolmen, D., Grossenbacher, K., Haffner, P., Lescure, J., Martens, H., Martínez Rica, J.P., Maurin, H., Oliveira, M.E., Sofianidou, T.S., Veith, M., Zuiderwijk, A. (Eds.), Atlas of Amphibians and Reptiles in Europe. Re-edition. Societas Europeae Herpetologica and Muséum national d'Histoire naturelle, Paris, pp. 495-516.

Crottini, A., Andreone, F., Kosuch, J., Borkin, L.J., Litvinchuk, S.N., Eggert, C., Veith, M., 2007. Fossorial but widespread: the phylogeography of the common spadefoot toad (Pelobates fuscus), and the role of the Po Valley as a major source of genetic variability. Mol. Ecol. 16, 2734-2754.
Ding, Z.L., Xiong, S.F., Sun, J.M., Yang, S.L., Gu, Z.Y., Liu, T.S., 1999. Pedostratigraphy and paleomagnetism of a 7.0 Ma eolian loess-red clay sequence at Lingtai, Loess Plateau, north-central China and the implications for paleomonsoon evolution. Palaeogeogr. Palaeoclimat. Palaeoecol. 152, 49-66.

Donghuai, S., Zhisheng, A., Shaw, J., Zhisheng, A., Bloemendal, J., Youbin, S., 1998. Magnetostratigraphy and palaeoclimatic significance of Late Tertiary aeolian sequences in the Chinese Loess Plateau. Geophys. J. Int. 134 207-212.

Drummond, A., Rambaut, A., 2007. BEAST: Bayesian evolutionary analysis by sampling trees. BMC Evol. Biol. 7, 214.

Duellman, W.E., Trueb, L., 1994. Biology of Amphibians. John Hopkins University Press, Baltimore, MD.

Fauquette, S., Suc, J.P., Bertini, A., Popescu, S.M., Warny, S., Taoufiq, N.B., Villa, M.J.P., Chikhi, H., Feddi, N., Subally, D., Clauzon, G., Ferrier, J., 2006. How much did climate force the Messinian salinity crisis? Quantified climatic conditions from pollen records in the Mediterranean region. Palaeogeogr. Palaeoclimat. Palaeoecol. 238, 281-301.

Felsenstein, J., 1985. Confidence limits on phylogenies: An approach using the bootstrap. Evolution 39, 783-791.

Fortelius, M., Eronen, J., Jernvall, J., Liu, L., Pushkina, D., Rinne, J., Tesakov, A. Vislobokova, I., Zhang, Z., Zhou, L., 2002. Fossil mammals resolve regional patterns of Eurasian climate change over 20 million years. Evol. Ecol. Res. 4, $1005-1016$.

Fortelius, M., Eronen, J., Liu, L., Pushkina, D., Tesakov, A., Vislobokova, I., Zhang, Z., 2006. Late Miocene and Pliocene large land mammals and climatic changes in Eurasia. Palaeogeogr. Palaeoclimat. Palaeoecol. 238, 219-227.

Fromhage, L., Vences, M., Veith, M., 2004. Testing alternative vicariance scenarios in Western Mediterranean discoglossid frogs. Mol. Phylogenet. Evol. 31, 308332.

Frost, D.R., 2011. Amphibian Species of the World: an Online Reference. Version 5.5. <http://research.amnh.org/vz/herpetology/amphibia/> (31.01.11).

Gasc, J.P., Cabela, A., Crnobrnja-Isailovič, J., Dolmen, D., Grossenbacher, K., Haffner P., Lescure, J., Martens, H., Martínez Rica, J.P., Maurin, H., Oliveira, M.E. Sofianidou, T.S., Veith, M., Zuiderwijk, A. (Eds.), 1997. Atlas of amphibians and reptiles in Europe. Collection Patrimoines Naturels, 29, Societas Europaea Herpetologica, Muséum National d'Histoire naturelle \& Service du Patrimone Naturel, Paris.

Geniez, P., Cheylan, M., 2005. Reptiles et Batraciens de France. CD-rom, Educagri, Dijon.

Geniez, P., Cheylan, M., in press. Les Amphibiens et les Reptiles du LanguedocRoussillon et régions limitrophes. Atlas biogéographique. Meridionalis, EPHE \& Biotope, Mèze (France).

Gómez, A., Lunt, D., 2007. Refugia within Refugia: patterns of Phylogeographic Concordance in the Iberian Peninsula. In: Weiss, N., Ferrand, N. (Eds.), Phylogeography of Southern European Refugia. Springer, pp. 155-188.

Grassi, F., De Mattia, F., Zecca, G., Sala, F., Labra, M., 2008. Historical isolation and quaternary range expansion of divergent lineages in wild grapevine. Biol. J. Linnean Soc. 95, 611-619.

Grill, A., Amori, G., Aloise, G., Lisi, I., Tosi, G., Wauters, L.A., Randi, E. 2009. Molecular phylogeography of European Sciurus vulgaris: refuge within refugia? Mol. Ecol. 18, 2687-2699.

Guicking, D., Lawson, R., Joger, U., Wink, M., 2006. Evolution and phylogeny of the genus Natrix (Serpentes: Colubridae). Biol. J. Linnean Soc. 87, 127-143.

Guo, Z.T., Sun, B., Zhang, Z.S., Peng, S.Z., Xiao, G.Q., Ge, J.Y., Hao, Q.Z., Qiao, Y.S., Liang, M.Y., Liu, J.F., Yin, Q.Z., Wei, J.J., 2008. A major reorganization of Asian climate by the early Miocene. Climate Past 4, 153-174.

Harris, D.J., Batista, V., Carretero, M.A., 2003. Diversity of $12 \mathrm{~S}$ mitochondrial DNA sequences in Iberian and northwest African water frogs across predicted geographic barriers. Herpetozoa 16, 81-83.

Hewitt, G., 2000. The genetic legacy of the quaternary ice ages. Nature 405, 907913.

Hijmans, R.J., Cameron, S.E., Parra, J.L., Jones, P.G., Jarvis, A., 2005. Very high resolution interpolated climate surfaces for global land areas. Int. J. Climatol. 25, 1965-1978.

Ho, S.Y.W., Saarma, U., Barnett, R., Haile, J., Shapiro, B., 2008. The effect of inappropriate calibration: three case studies in molecular ecology. PLoS ONE 3, 1-8.

Horn, A., Roux-Morabito, G., Lieutier, F., Kerdelhué, C., 2006. Phylogeographic structure and past history of the circum-Mediterranean species Tomicus destruens Woll. (Coleoptera: Scolytinae). Mol. Ecol. 15, 1603-1615.

Igawa, T., Kurabayashi, A., Nishioka, M., Sumida, M., 2006. Molecular phylogenetic relationship of toads distributed in the Far East and Europe inferred from the nucleotide sequences of mitochondrial DNA genes. Mol. Phylogenet. Evol. 38, 250-260.

Joger, U., Fritz, U., Guicking, D., Kalyabina-Hauf, S., Nagy, T.T., Wink, M., 2010. Relict populations and endemic clades in Palaearctic reptiles: evolutionary history and implications for conservation. In: Hebel, J.C., Assmann, T. (Eds.), Relict Species: Phylogeography and Conservation Biology. Springer, pp. 119-143.

Jost, A., Fauquette, S., Kageyama, M., Krinner, G., Ramstein, G., Suc, J.-P., Violette, S. 2009. High resolution climate and vegetation simulations of the Late Pliocene, a model-data comparison over western Europe and the Mediterranean region. Climate Past 5, 585-606.

Katoh, K., Misawa, K., Kuma, K., Miyata, T. 2002. MAFFT: a novel method for rapid multiple sequence alignment based on fast Fourier transform. Nucl. Acids Res. 30, 3059-3066.

Klicka, J., Zink, R.M., 1997. The importance of recent ice ages in speciation: a failed paradigm. Science 277, 1666-1669. 
fragmentation during the Pleistocene glaciations, possibly as a consequence of a single and wide Pleistocene refugium preserving a great amount of haplotypic diversity with little geographic fragmentation.

\subsection{Implications for the systematics of the Bufo bufo species complex}

Although a subspecies or species is not necessarily monophyletic for mtDNA haplotypes, when monophyly of mtDNA haplotypes characterizes a geographic population, that observation serves as a strong diagnostic criterion for a historically distinct lineage. The results of both mtDNA and allozyme analyses support the same five main population lineages within the Bufo bufo species complex but do not show congruence with the currently accepted taxonomy of the group. The monophyly tests performed with the mtDNA data set clearly rejected monophyly of Bufo bufo spinosus and Bufo bufo bufo as currently defined (see above). The three samples of Bufo b. gredosicola included in the mtDNA study branched within B. b. spinosus from the Iberian haplotype clade. However, further studies including morphology, fast-evolving nuclear markers and a better sampling at the population level are needed to assess the taxonomic validity of the population of Bufo bufo from the Sierra de Gredos (Lizana, 2002). Populations assigned to $B$. bufo spinosus based on their morphology and geographic distribution presented mtDNA and/or allozymes typical of $B$. b. bufo (Greece and Italy: localities 69, 108 and 117; Table 1; Figs. 1, 2 and 4) or Bufo verrucosissimus (Western Anatolia, localities 166 and 167; Table 1; Figs. 1, 2 and 4). Bufo b. spinosus is traditionally diagnosed mainly based on its body size and the degree of development of the keratinous warts. Our results suggest that these characters evolved independently multiple times towards the PeriMediterranean area, possibly as an adaptation to dry environments. The relationship between moisture and size has been proposed by Duellman and Trueb (1994), with larger animals having greater desiccation tolerance due to the decrease in body surface (especially so in "spherical" shapes like the toads). Moreover, the level of keratinization could be related to desiccation tolerance as well.

Based on the mtDNA and allozymic results, each one of the five main population lineages of the Bufo bufo species complex represent a different taxon. According to the phylogeny from Fig. 2 and the taxonomy of the group, the Caspian population should be recognized at the specific level as Bufo eichwaldi. The results of the MCA analyses (Fig. 4) and a close inspection of the allozyme frequency table (Supplementary material III) clearly show that some of the populations present a mixed ancestry indicating extensive past or ongoing introgression. For instance, Greek populations 69 and 117, which carry mtDNA of the European haplotype clade (Fig. 2), have an intermediate position between the Caucasian populations and the European populations in the MCA allozyme analysis (Fig. 4). The same occurs with specimens from locality 108 , assigned to the European population based on their mtDNA but with some Iberian alleles at some loci (Est-3, G6phd; see Fig. 4 and Supplementary material III), or with specimens from locality 45 , classified as belonging to the Iberian population based on their mtDNA but with European alleles in some loci (Fig. 4; Supplementary material III). As a result of the observed introgression between the different populations and until a more detailed study reveals the contact zones, we prefer to regard the Caucasian, European, Iberian and African populations as different subspecies of Bufo bufo. Moreover, any future analyses should attempt to add information on the morphology and bioacoustics of the different populations.

Based on the information on the type localities, the name Bufo bufo verrucosissimus should be used for the Caucasian population, Bufo bufo bufo for the European population, Bufo bufo spinosus should be restricted to the Iberian population and, until a new subspecies is described, Bufo bufo ssp. should be used for the African population. This latter population might, in fact, include two different subspecies, one in the Western Maghreb and another one in the Eastern Maghreb.

\section{Conclusions}

According to our results, the Bufo bufo and the Bufo gargarizans species complexes diverged during the Middle Miocene, most probably as a consequence of a climate-driven isolation coincident with an increase in the aridification of Central Asia. After this split between Eastern and Western complexes, at least three main lineages were generated within the Bufo bufo complex: (1) Caspian lineage (Bufo eichwaldi); (2) the Iberian-African lineage; and (3) the European-Caucasian lineage (Fig. 2). All these three splits were unambiguously placed in Pre-Pleistocene times according to our dating estimates, probably in the Late Miocene. We propose here that the cladogenetic events leading to these lineages could be mediated by the combination of paleogeographic features (as the Parathetys Sea) and the climate shift that occurred in Europe in the Late Miocene towards major levels of aridity and savanna-like environments.

A dispersion event leading to the colonization of Northern Africa occurred during the Pliocene, after the opening of the Gibraltar Strait, and this could be the first unambiguous case of overseas dispersal across the Gibraltar Strait for an amphibian.

The structure of the European-Caucasian populations involved at least two major reorganizations during the Pleistocene, with an older split between the European lineage and the Caucasian lineage, possibly involving the Caucasus as a Pleistocene refugium, and other shallower structuring mediated by more recent Pleistocene glaciations. These promoted high levels of geographic fragmentation and genetic differentiation in the European and Caucasian lineages. This more recent structuring is compatible with the range fluctuations experienced by Paleartic faunas during the Pleistocene concomitant to glacial events. We propose seven Pleistocene refugia, four Mediterranean refugia involving the Iberian and Italian peninsulas, the South Balkanic region and Anatolia, and three refugia with diffuse locations that together form an extensive Central European group (see Figs. 2, 3 and 7). These latter refugia were the most probable source for the recolonization of northern Europe after the ice withdrew. In contrast, the Iberian Peninsula seems not to have any structure coupled with geography, and this is probably the consequence of a single wide refugium retaining great amounts of ancestral polymorphism.

\section{Acknowledgments}

The following persons contributed greatly in some part of the process of this study, either during the fieldtrips, lab part or either reading the manuscript and providing helpful improvements: Kim Roelants, Franky Bossuyt, An Mannaert, Wim Vandebergh, Ines van Bocklaer, Ignasi Castellvi, Juan G. Renom, Isaac Casanovas-Vilar, Jose Castresana, Victor Soria-Carrasco, Alejandro Sanchez-Gracia, Emma Duran Alsina, Pere Garcia-Porta, Miquel A. Arnedo, Pedro Abellán, Mar Comas, Daniel Escoriza, David Donaire, Grégory Deso, Alexandre Teynié, Philip de Pous, Diego Alvarado-Serrano, Josep Roca and Javier Igea. The first author is recipient of a pre-doctoral research fellowship (JAE) from the CSIC. The work was partially funded by Grants CGL2008-00827 and CGL2009-11663 from the Ministerio de Educación y Ciencia, Spain to SC. S.N. Litvinchuk was partly supported by Grants NSh-3299.2010.4 and MCBN22n. Comments by the Editor and two anonymous reviewers improved the manuscript. 
ocene Western Europe was overall wetter than today (Jost et al., 2009), probably rains were never intense enough to produce a substantial decrease in seawater salinity. However great Iberian rivers, such as the Guadalquivir, could have had an important role in projecting rafts into the open water, which afterwards could have reached the North African coast through the currents. In the particular case of Bufo bufo, it is known that brackish waters do not prevent animals from swimming in open water in the North Baltic Sea, even allowing gene flow between islands (Seppa and Laurila, 1999), indicating a certain degree of salt tolerance in this species.

The African group comprises two highly supported subgroups corresponding to Moroccan versus Tunisian populations (Figs. 2 4), although in the NJ tree from Fig. 4c the African group is not monophyletic. This same pattern of high level of genetic variability in North Africa has been observed in several other groups, as for instance the lacertid lizard Timon tangitanus/Timon pater (Paulo et al., 2008), the frogs Hyla meridionalis (Recuero et al., 2007; Stöck et al., 2008a) and Pelophylax saharicus (Harris et al., 2003), the toad Discoglossus scovazzi/Discoglossus pictus auritus (Zangari et al., 2006), and the snakes Natrix maura (Guicking et al., 2006), Natrix natrix and Coronella girondica (pers. observ.). The arid conditions of the Moulouya Basin could explain this dichotomy, as evidenced by the gap in the potential distribution of the Bufo bufo species complex in North Africa (results not shown). However, because of our lack of samples in the wide area existing between our Easternmost Moroccan samples and our Tunisian samples (mainly Algeria), we cannot know with certainty whether the Moulouya Basin represents the vicariant event that separated these populations.

\subsection{Effects of glaciations}

The Caucasian populations comprise three distinct subgroups (c1-c3; Fig. 2) and the European populations up to seven subgroups (e1-e7; Fig. 2). According to our dating estimates (Fig. 5) this structuring occurred during the Pleistocene and can be interpreted as signatures of the Quaternary glacial events, implying several cycles of retraction/expansion of the population ranges accompanied by strong effects of sorting of ancestral polymorphisms (Hewitt, 2000). The nested pattern observed in the European-Caucasian group suggests that at least two heterochronous events shaped its inner structure. The first event could have involved the Caucasian region as Pleistocene refugia, although we cannot exclude the possibility of an extra-Caucasian split with a posterior population retraction into the Caucasus. Secondary glacial events produced the youngest fragmentations, which, based on their strong geographic association, suggest that up to seven refugia could have existed (Figs. 2, 3 and 7).

The Caucasus appears in many phylogeographies as a source of distinctive lineages, involving cases of recent glacial-driven splits (Grassi et al., 2008). Paleopalinological data indicate the presence of a mild climate in the area during the LGM, as can be inferred from the presence of conifer and mixed forests in the Western Caucasus $18 \mathrm{Ka}$ (Tarasov et al., 2000). This is congruent with our LGM projections that show the area as climatically suitable for the species and greatly isolated, supporting the hypothesis that it could have acted as a Pleistocene refugium (Fig. 7).

The structuring of the European populations is congruent with the existence of four Pleistocene refugia in the Mediterranean region and three refugia in Central Europe (see Figs. 2, 3 and 7). The Mediterranean refugia encompass Southern Italy (e7), Central/Northern Italy (e6), Greece (e5) and Anatolia (e4), and all of them have been reported as Pleistocene refugia for many groups, conforming to the Adriatic-Mediterranean and Pontic-Mediterranean elements based on chorological analysis (Schmitt, 2007). The existence of more than one phylogroup in the Italian Peninsula is a very common pattern in other Mediterranean Peninsulas, revealing so-called "refugia within refugia" (Gómez and Lunt, 2007). The main phylogeographic feature found in many Italian taxa is the presence of distinctive lineages in the Sicilian-Southern Italian region, as observed for instance in the mammal Sciurus vulgaris (Grill et al., 2009), reptiles Hierophis viridiflavus and Zamenis longissimus/Zamenis lineatus (Joger et al., 2010) and amphibians Bombina pachypus (Canestrelli et al., 2006) and Hyla intermedia (Canestrelli et al., 2007). Our results match this pattern, with a clearly differentiated Southern Italian haplotype group distributed across Sicily and Southern Italy.

The genetic differentiation of the South Italian biotas has been attributed to two major physiographic features in the region, the Crati-Sibari graben and the Catanzaro graben, which have been repeatedly marine-flooded following glacio-eustatic sea-level fluctuations during the Upper Pliocene and Pleistocene, interrupting or reducing the genetic exchange with the rest of the Italian Peninsula (Santucci and Nascetti, 1996; Canestrelli et al., 2007; and references therein). However, considering the patchy distribution pattern observed in our climatic projection under the CCSM paleoclimatic scenario, we do not exclude a climatically driven isolation during the Pleistocene glaciations.

The Anatolian refugium was already suggested for Bufo bufo by Kutrup et al. (2006), and this is consistent with our Anatolian haplotype group, which is distributed from the Eastern Balkans-Western Anatolia to Eastern Anatolia (e4; Figs. 2 and 3). A similar phylogeographic pattern occurs in the reptile Zamenis longissimus (Joger et al., 2010) and several species of mammals (Randi, 2007; and references therein). The presence of a cool temperate forest has been proposed for a narrow band along the southern shore of the Black Sea 18 ka (Adams and Faure, 1997), supporting the putative role of this region as a glacial refugium.

Three subclades can be geographically associated with Central Europe, all of them phylogenetically closely related (see Figs. 2, 3 and 7): a South-Central European clade (e3) including Southern France, the Alpine region and Northern Balkans, a North-Central European clade (e1) encompassing Great Britain, Scandinavia, the North-Central European mainland reaching Western Russia and Ukraine, and a Southwestern European clade (e2) containing the localities of Gap and Altier in Southwestern France. Clades tightly associated with Central Europe have been reported for many groups. In the case of amphibians, these have been noted for Rana arvalis (Babik et al., 2004), Rana temporaria (Palo et al., 2004) and even in thermophilous species such as Epidalea calamita (Rowe et al., 2006). These phylogeographic patterns suggest the existence of Northern "cryptic" refugia for several species, and the existence of these refugia has been unambiguously corroborated on the basis of paleopalynology, paleontology (Stewart and Lister, 2001) and paleoclimatic modeling (Svenning et al., 2008). Our niche projection onto the MIROC paleoclimatic scenario indicates that suitable LGM climatic conditions could have existed across Central Europe for the European populations, supporting the possibility that the Central European populations could correspond to Northern "cryptic" refugia for the species; however, we cannot exclude the possibility that these populations could have originated from refugia located in the Northern Balkans (North-Central European clade) or the submediterranean areas of South-Central Europe (Southwestern and South-Central European clades), which also contained suitable areas for the species during the LGM according to our paleoclimatic projection (Fig. 7).

In the Iberian Peninsula, the Iberian populations fail to show a clear phylogeographic pattern, and this agrees with a previous genetic survey of Iberian populations using microsatellites and the mitochondrial control region revealing little population differentiation and extensive gene flow at a wide spatial scale (Martinez-Solano and Gonzalez, 2008). This suggests that the Iberian populations did not experience a great amount of population 


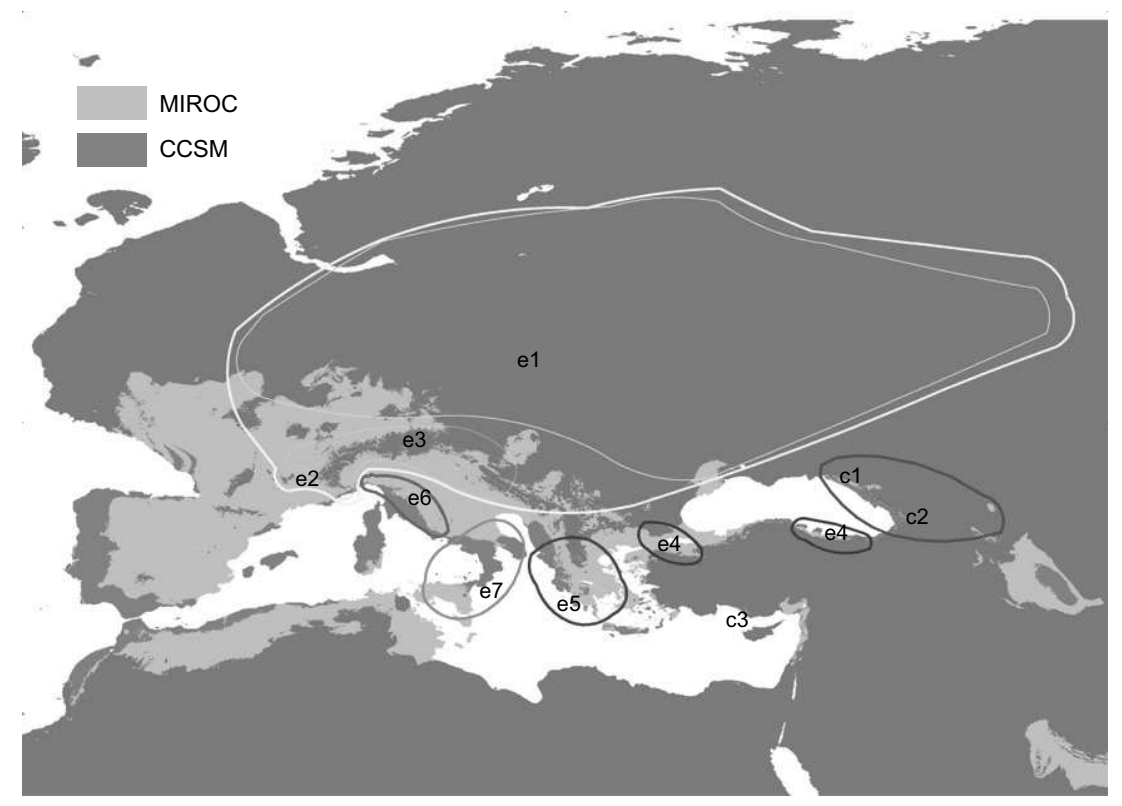

Fig. 7. Potential distribution of the European-Caucasian clade on two paleoclimatic scenarios during the LGM: MIROC (light orange) and CCSM (dark orange). The outlines represent the internal structure of the European-Caucasian clades. The colors and codes of the outlines have correspondence with those employed in Figs. 2 and 3. (For interpretation of the references to color in this figure legend, the reader is referred to the web version of this article.)

another case of Central Asian vicariance, has been established between 13.8 and 6.6 Ma (Roelants et al., 2007) and between 20.9 and 5.1 Ma (Zheng et al., 2009). These values are also compatible with our dating estimates.

All this evidence points to the complete isolation of lineages triggered by an increase in the arid conditions in the Central Asian region, supporting a climate-driven isolation between Eastern and Western species complexes as proposed by Savage (1973) and Borkin (1984).

\subsection{Major splits in the Western Palearctic}

Between the Late Miocene and Early Pliocene (11.6-3.6 Ma) two successive splits occurred: the separation of the lineage leading to Bufo eichwaldi (Caspian clade) from the rest and the separation between the ancestor of the European and Caucasian populations and the ancestor of the Iberian and African populations (Fig. 5). Several other cladogenetic events in amphibians have been reported in Europe within the same temporal frame: Bombina bombina/Bombina variegata (Fromhage et al., 2004), Triturus vulgaris/Triturus montandoni (Zajc and Arntzen, 1999), Pelophylax fortis/Pelophylax ridibundus (Akin et al., 2010), Hyla arborea/Hyla orientalis (Stöck et al., 2008a,b), and possibly the Eastern and Western lineages of P. fuscus (Crottini et al., 2007). The existence of the Parathetys Sea following an Eastern-Western axis in Central-Eastern Europe during the Miocene has been proposed to explain the split between the snakes, Natrix natrix and Natrix tessellata (Guicking et al., 2006), as a consequence of a North-South vicariance. This same vicariance could also explain the divergence between the Caspian population from the remaining populations of the Bufo bufo species complex given that the Paratethys Sea partially isolated what are now the Caucasus and the Southern Caspian shore from the rest of Europe during the Late Miocene (Popov et al., 2006).

However, the Late Miocene is also a period of a severe climatic and ecological reorganization already initiated around $10 \mathrm{Ma}$, when the European continent progressively shifted from more or less homogeneous humid conditions to drier conditions with higher levels of climatic and ecological heterogeneity. In fact, the Middle Turolian (7.6-6.8 Ma) is a period of upsurge of dry and open habitats as can be deduced from the great expansion of the savanna-adapted Pikermian faunas (Solounias et al., 1999) and the paleopalinologic record (fossil pollen and spores) (Fauquette et al., 2006). However it is between the Middle and Late Turolian (7-5 Ma) when the major break in climatic conditions occurred according to the levels of mammalian hypsodonty, with a transient phase of strong aridity dominating a large part of continental Europe (Fortelius et al., 2002, 2006; Van Dam, 2006). We hypothesize that this paleoclimatic scenario is congruent with severe changes in the population ranges of mesophilic amphibians, which eventually could lead to cladogenetic events.

4.3. Overseas dispersal across the Strait of Gibraltar and North African genetic structure

According to our mtDNA phylogenetic results (Fig. 2), North Africa was colonized from the Iberian Peninsula. Our dating estimates place the split between the Iberian and African clades clearly after the reopening of the Gibraltar Strait, implying overseas dispersal (Fig. 5). So far, this same mode of dispersal has been proposed for some mammals (Cosson et al., 2005), many reptiles (Carranza et al., 2004; Carranza et al., 2006; see Pleguezuelos et al., 2008 for a review), some invertebrates (e. g. Horn et al., 2006) and, regarding amphibians, it has been suggested for some lineages of Pleurodeles waltl (Veith et al., 2004; Carranza and Arnold, 2004; Carranza and Wade, 2004) and Hyla meridionalis (Recuero et al., 2007), although in both cases human-mediated dispersal cannot be fully excluded. In the Mediterranean basin, overseas dispersal from Africa to Europe has been suggested for the Bufotes viridis species complex (Stöck et al., 2008b).

The dispersal capabilities of amphibians across the sea have been evidenced several times despite the apparent severe limitations that salt water imposes to their physiology (Measey et al., 2007; Vences et al., 2003). Some of the best known events of overseas dispersal by amphibians seem to be mediated by the combination of two factors: (1) great rivers able to expel islets of soil and vegetation a long way into the open sea; and (2) long-persisting torrential rains that can greatly reduce the salinity across the oceanic dispersal path (Measey et al., 2007). Although during the Pli- 


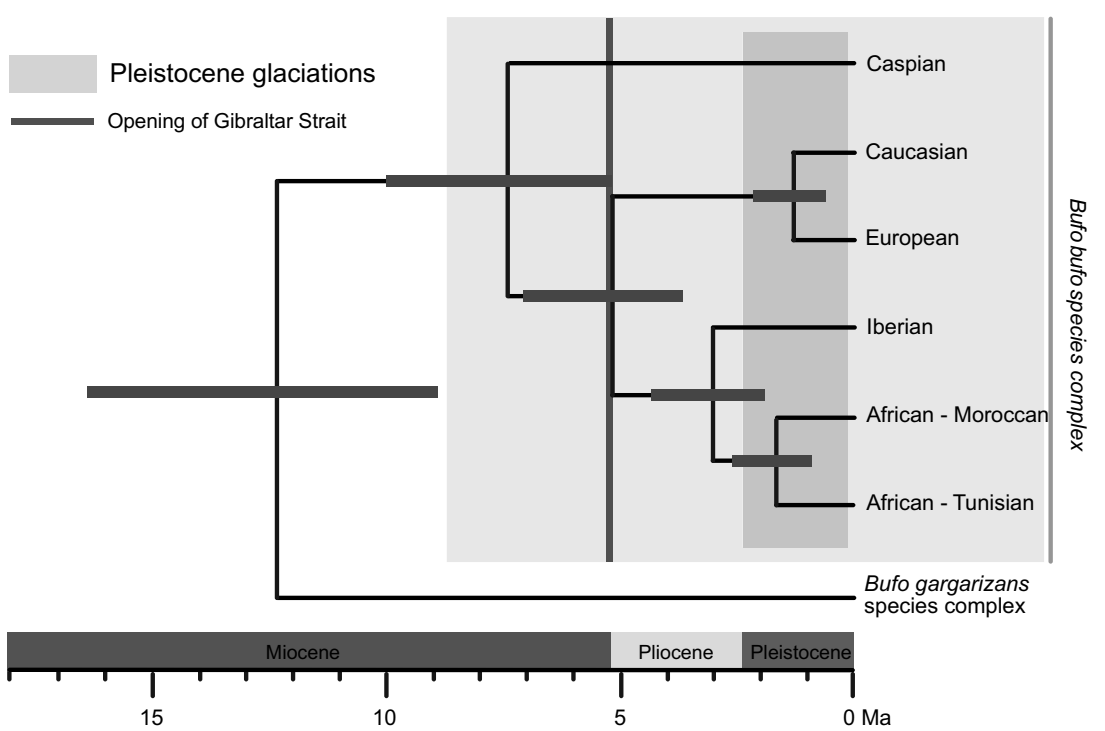

Fig. 5. Enlarged view of the Bayesian time-calibrated tree (Supplementary material II) showing the divergence times within the Bufo bufo species complex. The horizontal bars indicate the $95 \%$ posterior age intervals.

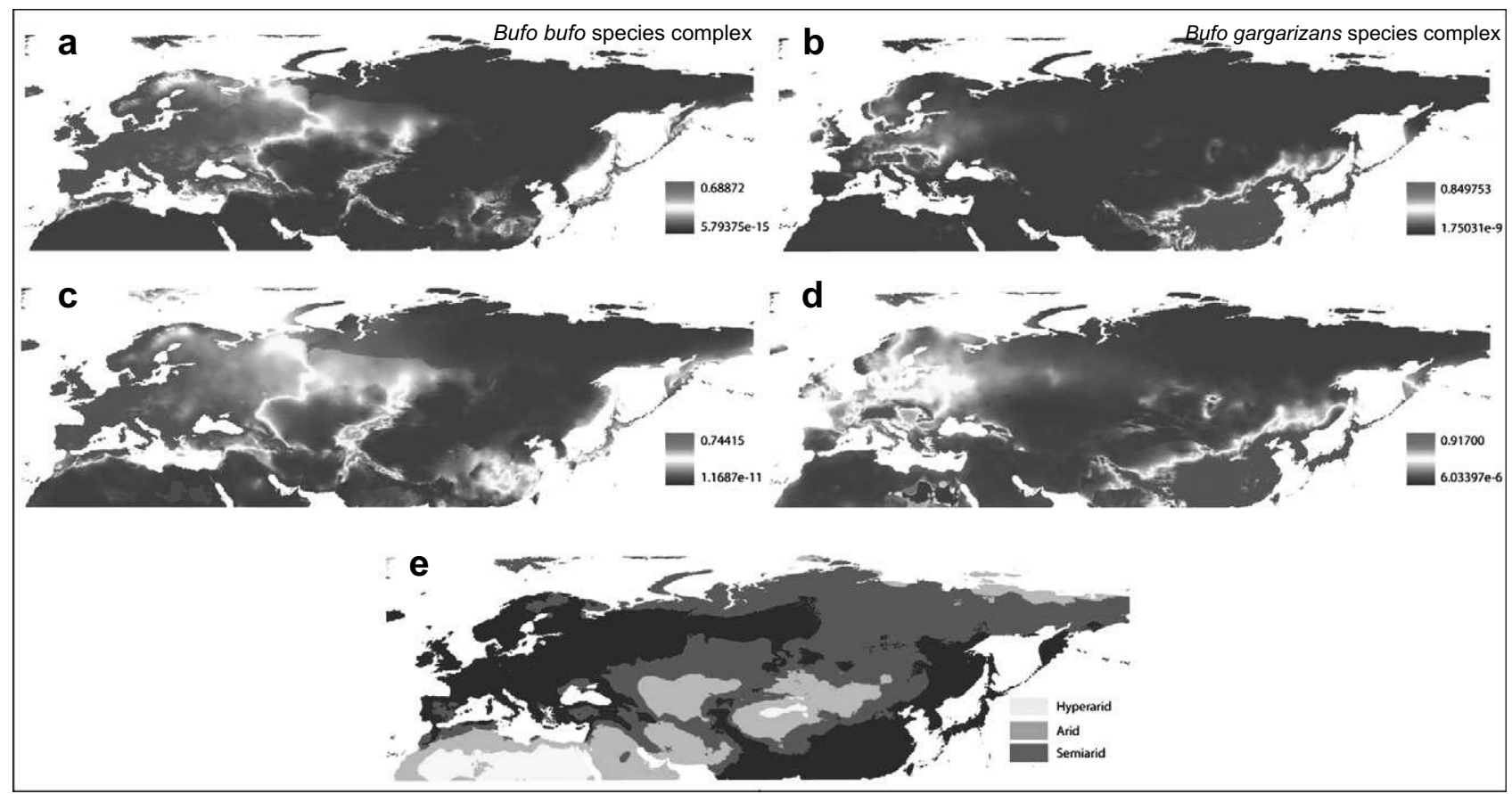

Fig. 6. Potential distribution of the Bufo bufo species complex and the Bufo gargarizans species complex across Eurasia, with different regularization factors: $a$ and $b=9, c$ and $d=50$. The map $e$ shows the current extent of the desertic and subdesertic areas in Central Asia. The color gradient next to each map indicates the predicted probability that environmental conditions are suitable for the species. (For interpretation of the references to color in this figure legend, the reader is referred to the web version of this article.)

imately 15 and 8 Ma (Wan et al., 2007). This estimate matches those of several studies from widely separated places in the Eastern part of China's Loess Plateau, which show initial accumulation of loess between 10-8 Ma (Donghuai et al., 1998; Ding et al., 1999; Qiang et al., 2001).

From a paleobiological perspective, major levels of mean hypsodonty (dentition characterized by high-crowned teeth, typical of species inhabiting arid habitats) are observed in the large mammal faunas of Central China during the early Late Miocene (11.19.7 Ma), indicating an increase in aridity during this time interval (Liu et al., 2009). Moreover, the palynological record of the Northeastern margin of Tibet also reflects a marked shift towards more arid landscapes around 9 Ma (Ma et al., 1998; Sun and Wang, 2005).

Other diversification events fully agree with the development of the Central Asian Deserts during the Middle Miocene (15.9-11.6), either as an effective biogeographic barrier or as a source of new habitats that enhanced arid-adapted species radiations. An example of the latter is the origin of the radiation of desert-adapted lizards of the genus Phrynocephalus which, for Central Asia, dates between 17 and $11 \mathrm{Ma}$ (Melville et al., 2009), according to the existing overlap of the $95 \%$ HPD between the estimates of the mitochondrial and nuclear markers. Moreover, the dating of the split between the Eastern and Western species complexes of Bombina, 

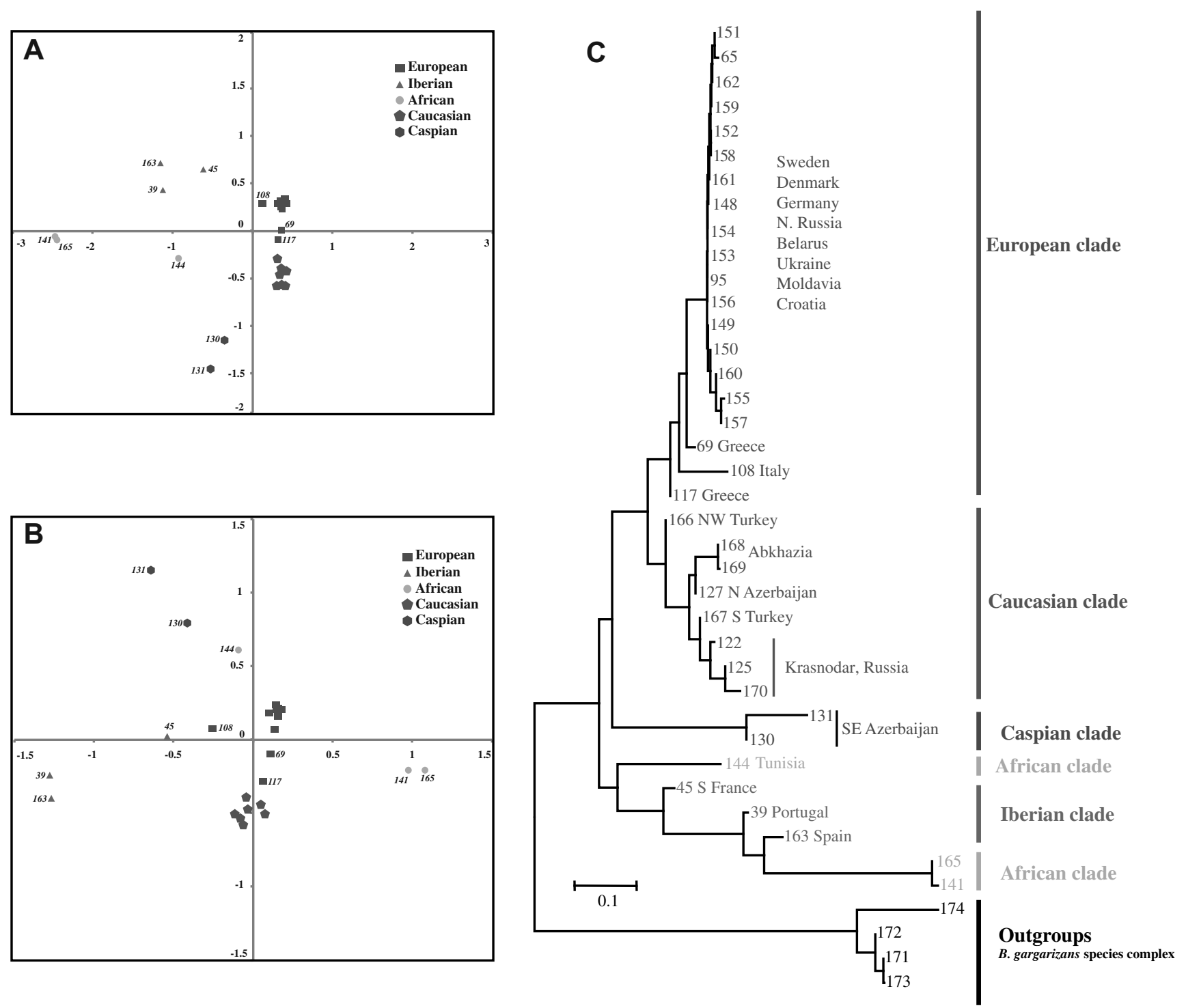

Fig. 4. Multiple Correspondence Analysis (MCA) of Bufo populations and neighbor-joining tree based on Nei's genetic distances among populations based on allozyme data. Data on the allozyme frequencies can be found in Supplementary material III. Information on the specimens analyzed can be found in Table 1 and their geographic position is shown in Fig. 1. (A) Biplot of factor 1 and 2 scores of the MCA analysis; (B) biplot of factors 3 and 4 of the MCA analyses. Scores along the first four axes for the MCA analyses can be found in Supplementary material V. (C) Neighbor-joining tree. The colors and codes have correspondence with those employed in Figs. 2 and 3. (For interpretation of the references to color in this figure legend, the reader is referred to the web version of this article.)

clade, with no suitable climate predicted above $53^{\circ}$ of latitude in Central Europe (Fig. 7). The extent of range shrinkage is variable depending on the climatic model, being more severe under the CCSM and more relaxed under the MIROC. In both cases all Mediterranean Peninsulas, Anatolia and Caucasus appear suitable with different degrees of range fragmentation depending on the model. A substantial area in central Europe appears to be appropriate for the species according to the MIROC model.

\section{Discussion}

\subsection{The role of the Central Asian Deserts as a biogeographic barrier}

Our calibrated timetree sets the age of the split between Bufo bufo and Bufo gargarizans species complexes around $12.33 \mathrm{Ma}$ (95\% Highest Posterior Density $=8.81-16.36 \mathrm{Ma}$ ), and this is compatible with the oldest fossil attributable to the genus Bufo sensu stricto. This fossil from Suchomasty (Czech Republic) was dated to the MN9 (11.1-9.7 Ma) by Rage and Roček (2003), although Mein (1999), based on mammal faunas, assigned the locality to the MN10 (9.7-8.7 Ma) (Agustí et al., 2001).

Our distribution models (Fig. 6) show that both species complexes are completely isolated by the arid areas of Central Asia, a result congruent with a scenario of a climate-driven isolation between these two species complexes assuming niche conservatism during the last $10 \mathrm{My}$. However, our estimate of $12.33 \mathrm{Ma}$ for the timing of this vicariant event (Fig. 5) does not match the most recent geological studies based on Loess deposits in China, which show that the Central Asian inland deserts originated in the Early Miocene, $22 \mathrm{Ma}$ (Guo et al., 2008) or even $24 \mathrm{Ma}$ (Sun et al., 2010). Despite that, the event that separated these two species complexes was probably not the geological origin of the Central Asian Deserts but their emergence as biogeographic barriers, and these two phenomena do not necessarily have to be synchronous. In fact, mineralogical and sedimentological records of the Northern-South China Sea show that the aridification process of Central Asia was not a homogeneous process but encompassed several pulses of accelerated aridification, with two great pulses at approx- 


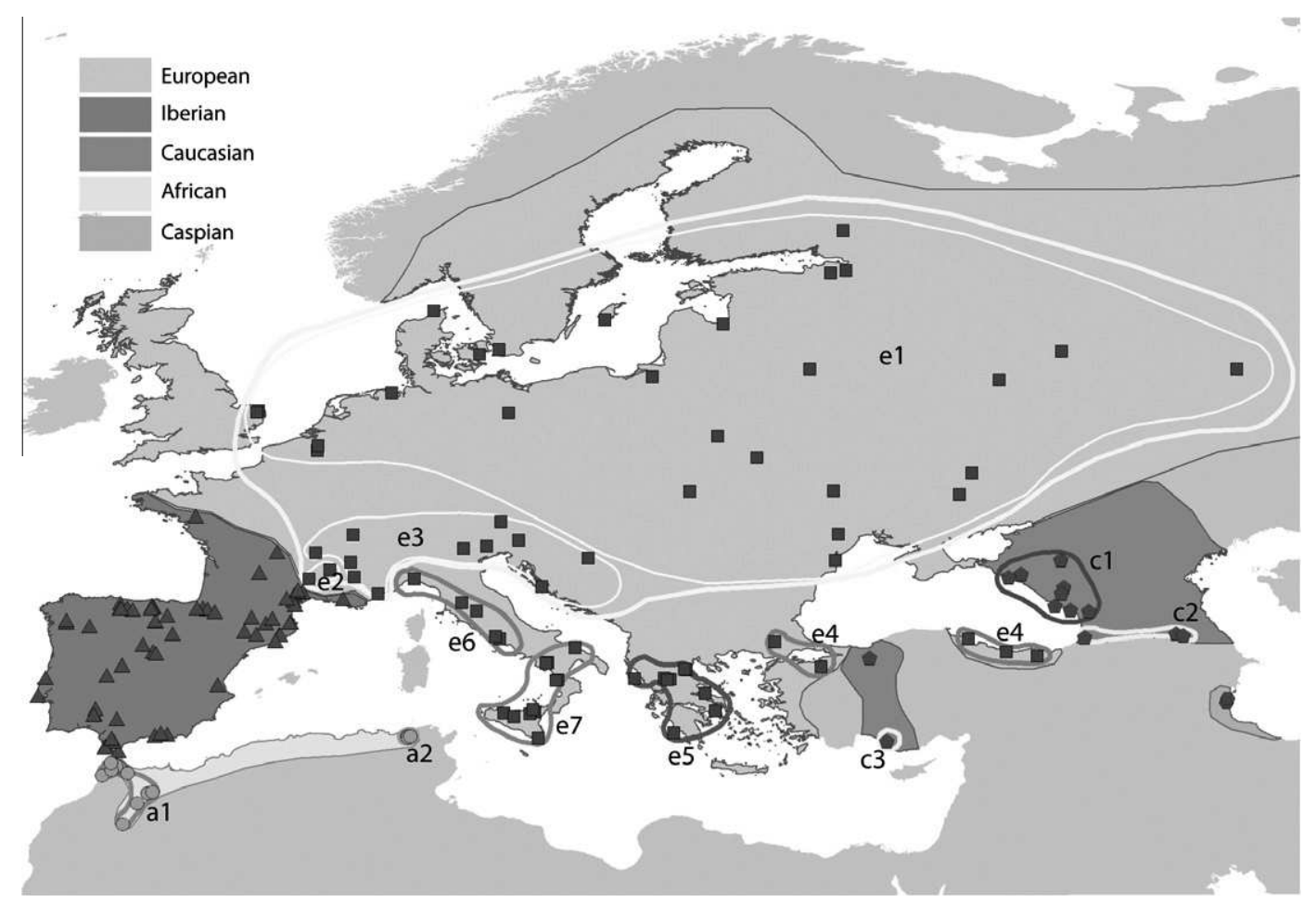

Fig. 3. Map showing the geographic distribution of the major clades (mitochondrial) and MCA groups (allozymes) recovered in our analyses (background colors). The outlines depict the shallow phylogenetic structure. The colors and codes have correspondence with those employed in Fig. 2 and in the text. Morocco (a1), Tunisia (a2), North-Central Europe (e1), Southwestern Europe (e2), South-Central Europe (e3), Anatolia (including Northeastern Greece) (e4), Greek Peninsula (e5), North-Central Italy (e6), Southern Italy (e7), North Caucasus (c1), South Caucasus (c2), Central Anatolia (c3). (For interpretation of the references to color in this figure legend, the reader is referred to the web version of this article.)

Table 2

Estimates of evolutionary divergence over sequence pairs between clades in terms of the number of base differences per site ( $p$-distance) from averaging over all sequence pairs. Upper right, distances for the 16S; lower left, distances for the ND1.

\begin{tabular}{llllll}
\hline Clades & Caucasian & European & Iberian & African & Caspian \\
\hline Caucasian & - & 0.009 & 0.041 & 0.049 & 0.038 \\
European & 0.034 & - & 0.043 & 0.050 & 0.039 \\
Iberian & 0.100 & 0.093 & - & 0.034 & 0.047 \\
African & 0.096 & 0.093 & 0.054 & - & 0.057 \\
Caspian & 0.116 & 0.117 & 0.095 & 0.099 & - \\
\hline
\end{tabular}

nies of this family (Van Bocxlaer et al., 2009, 2010), and all the nodes involving the Bufo bufo species complex were recovered with the highest possible support (posterior probability of 1) (Supplementary material II).

The crown age of the family Bufonidae was estimated at approximately $60 \mathrm{Ma}(95 \% \mathrm{HDP}=47.94-75.48 \mathrm{Ma})$, compatible with previous estimates (Roelants et al., 2007; Van Bocxlaer et al., 2009, 2010) and with the age of the oldest fossil attributable to the family Bufonidae (55 Ma old) (Báez and Nicoli, 2004).

Regarding our ingroup (Fig. 5), the age of the split between the Bufo bufo and the Bufo gargarizans species complexes was estimated at $12.33 \mathrm{Ma}$ (95\% Highest Posterior Density $=8.81$ 16.36 Ma). The separation between Bufo eichwaldi and the main European populations occurred approximately $7.42 \mathrm{Ma}(95 \%$ $\mathrm{HPD}=5.15-9.99 \mathrm{Ma}$ ) and was followed by the split between the ancestor of the European and Caucasian populations and the ancestor of the Iberian and African populations, which occurred around $5.21 \mathrm{Ma}(95 \% \mathrm{HPD}=3.67-7.11 \mathrm{Ma})$. Finally, our dating estimates place the separation between the Iberian and the African populations at $3.07 \mathrm{Ma}(95 \% \mathrm{HPD}=1.91-4.36 \mathrm{Ma})$, with the remaining splits occurring within the Pleistocene (Fig. 5).

\subsection{Distribution modeling}

\subsubsection{The Central Asian Deserts as a biogeographic barrier}

All distribution models of both species complexes across Eurasia produced either independently or pooled provided mean AUC values beyond 0.9 and significance for all binomial omission tests, indicating a good performance of the models (data not shown). As shown in Fig. 6, although suitable climatic conditions for both species complexes seem to exist along the Himalayan range, implying a possible contact zone, the genus Bufo has never been reported in this region, which instead is occupied by the Indian-radiated genus Duttaphrynus and the widespread Palearctic genus Bufotes (Van Bocxlaer et al., 2009; Frost, 2011). Therefore, excluding this predicted contact zone, the distributions of both species complexes appear to be disjoint and nowadays completely isolated by the hyperarid, arid and semiarid regions of Central Asia. This pattern of isolation between both species complexes was resilient to the increase of the regularization values from 1 to 50 , although each increment of the value produced more spread-out distributions.

\subsubsection{Glaciations as drivers of phylogeographic structure}

Modeling of distribution of populations of the European mtDNA clade yielded, on the current climate conditions, a mean test AUC score of 0.856 , and all thresholds measured by the binomial omission tests were significantly nonrandom (data not shown). A visual inspection of the predicted distribution under the current climatic conditions showed overall an adequate fit to the distributions of the species as presented in Gasc et al. (1997) (data not shown).

The distribution models based on the LGM conditions indicate a substantial southward retraction of the ranges for the European 


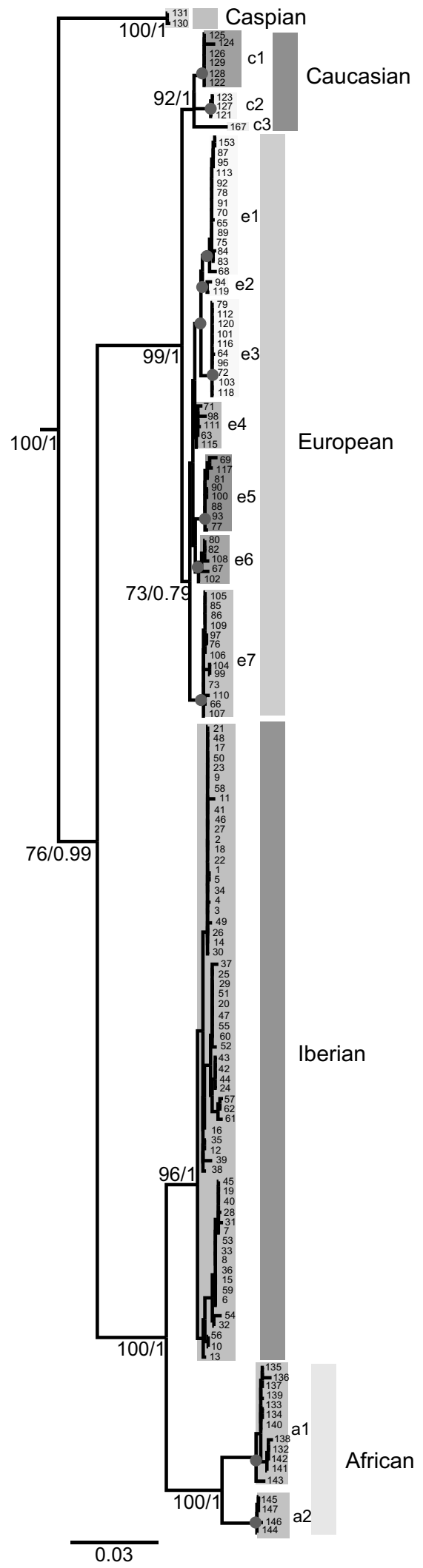

Fig. 2. Phylogenetic relationships of the Bufo bufo species complex in the Western Palearctic, as inferred from the ML analysis of $1988 \mathrm{bp}$ of mtDNA. The support values (bootstrap/pp) are shown next to the nodes of the major splits. The red dots depicted in the shallow splits denote a bootstrap value equal or higher than $80 \%$ and simultaneously a posterior probability equal or higher than 0.90 . The reference bar is expressed in substitutions per site. Numbers at the tips of the tree refer to specimens listed in Table 1. The outgroups have been removed. (For interpretation of the references to color in this figure legend, the reader is referred to the web version of this article.) of the precise geographic contact between these two clades. The Moroccan clade presents some genetic differentiation between the population from the Great Atlas and the populations from the Rif/Middle Atlas.

\subsection{Allozymes}

Allele frequencies, sample size, percentage of polymorphic loci, and average heterozygosity are presented in Supplementary material III. Among 21 presumptive loci, 16 are polymorphic and include between two and seven alleles. The MCA analysis of allozyme variation is presented in Fig. 4. The populations are grouped according to the five mtDNA clades (Fig. 2) and not according to the current taxonomy (see Table 1). Specimens from localities 69, 108 and 117 (Table 1 ), classified as $B$. $b$. spinosus, in fact present mtDNA and allozymes of $B$. b. bufo, while specimens from localities 166 and 167 , also classified as $B$. $b$. spinosus, group with $B$. verrucosissimus. Based on the fact that multiple independent nuclear loci are more likely to reflect evolutionary history than the mitochondrial locus, the six main mtDNA clades thus seem to correspond to the real evolutionary history of the Bufo bufo species complex. However, the NJ tree (Fig. 4c) based on Nei's genetic distances among populations (Supplementary material IV) does not recover the African and Iberian populations as monophyletic.

A number of populations occupy an intermediate position in the MCA scatter plots (Fig. 4a and b) and exhibit a mix of alleles typical of more than one lineage (Supplementary material III; see also Supplementary material $\mathrm{V}$ for scores along the first four axes for the MCA analyses). The Greek populations 69 and 117 have an intermediate position between the Caucasian and European groups, and it is clearly not an artifact, as these populations exhibit a mix of Caucasian and European alleles, indicating mixed ancestry of the Greek populations (Supplementary material III). The single individual analyzed from locality 108 (Italy) carries mostly European alleles, confirming its assignment based on mtDNA (Fig. 2), but it also presents at two loci (Est-3, G6pdh) Iberian alleles that are not found in any other individual of the Caucasian or European populations. Specimens from another locality (locality 45; Lac du Saut de Vésoles, S. France) occupy an intermediate position in the MCA scatter plots between the European and Iberian clades (Fig. 4). Its mtDNA places it with the Iberian clade, but its nuclear DNA exhibits both European and Iberian alleles (Supplementary material III). Both the Caspian and Caucasian populations are well separated in the MCA analysis.

The average Nei's genetic distances among the five clades are shown in Supplementary material VI. All the clades are genetically very well differentiated (Nei's genetic distance: 0.1960.632). The lower genetic distance corresponds to the comparison between the Caucasian and European clades and the highest to the comparison between the Caucasian and African clades. The European populations sampled for the allozyme study (see Fig. 1 and Table 1) present a low level of genetic differentiation (average Nei's genetic distance: 0.010), despite being from localities as far away as Denmark, Sweden, Germany, Croatia, Russia, Belarus, Moldova and Ukraine. In contrast, the Moroccan and Tunisian populations of the African mtDNA clade are genetically very distinct (Nei's genetic distance: 0.349 ). This value is comparable to the genetic distance between the Iberian and African populations (see Supplementary material VI) and supports the distinctiveness of these three lineages obtained in the mtDNA phylogenetic analysis.

\subsection{Dating estimates}

Our BRMC calibrated ultrametric tree for all Bufonidae yielded most of the clades compatible with previously published phyloge- 
The models were generated by Maxent 3.3.1 (Phillips et al., 2006; Phillips and Dudík, 2008). To avoid highly correlated and redundant climatic variables in our climatic dataset, which can cause over-parametrization and loss of predictive power (Williams et al., 2003; Buermann et al., 2008), the environmental data from 10,000 randomly generated points from across the study area were extracted and, from there, the level of correlation between pairs of variables was analyzed using the Pearson correlation coefficient. When two variables shared a correlation coefficient of 0.80 or higher, these were considered highly correlated, and the most meaningful variable was selected according to the physiological requirements of a typical mesophilic amphibian. Following this criterion, of the 19 variables available, eight variables were retained as input data for the distribution models: Bio1 (annual mean temperature), Bio2 (mean diurnal range), Bio7 (temperature annual range), Bio8 (mean temperature of wettest quarter), Bio12 (annual precipitation), Bio13 (precipitation of the wettest period), Bio15 (precipitation seasonality) and Bio18 (precipitation of the warmest quarter).

We generated models for each species complex independently and models pooling the localities of both species complexes. In both cases, we generated eight sets of 50 replicates of the distribution models, every set with increasing regularization values $(1,3,5$, $9,20,30,40$ and 50). By doing so, we progressively reduced the overfitting of our data in every replicate, producing more spreadout potential distributions (Phillips et al., 2006). The rationale is to extend as much as possible the distribution of both species complexes in all possible directions to test the stability of the Central Asian Deserts as a biogeographic barrier. Convergence threshold and maximum number of iterations corresponded to default settings of the program $(0.00001,500$ respectively). For each set, we considered the mean of the 50 models the best estimate for the potential limits for both species. Model performance was evaluated using the AUC and the threshold-dependent binomial omission tests calculated by Maxent.

\subsubsection{Testing the effects of glaciations}

We explored whether the range shifts and population fragmentation experienced by the species during the Late Quaternary (0.0117-0.126 Ma) were congruent with the shallow phylogenetic structure of the European-Caucasian clade (the clade with the highest degree of geographic structure, see results). Localities corresponding to the European-Caucasian clade were projected onto the current climate and, assuming niche stability during the last 18,000 years (Nogués-Bravo, 2009), onto two possible reconstructions of the climatic conditions during the last glacial maximum (LGM), which were based on two models: the Community Climate System Model (CCSM) and the Model for Interdisciplinary research on Climate (MIROC). The climatic layers from the current and past scenarios were downloaded from the WorldClim (http:// www.worldclim.org) database at 2.5' spatial resolution. The methodology used to generate the layers can be found in Waltari et al. (2007) and Hijmans et al. (2005).

Both present-day and past distribution models were generated through 100 replicates with Maxent 3.3.1 (Phillips et al., 2006; Phillips and Dudík, 2008) using the same climatic layers previously selected. To the 89 georeferenced localities of the EuropeanCaucasian clade obtained by ourselves, we added 30 localities selected from Gbif (http://www.gbif.org) to cover the less-sampled areas. In each replicate, $70 \%$ of the localities were used to train the model and 30\% to test it. The model calibrated with the presentday occurrence data was projected onto the current climate and past climatic conditions. Convergence threshold, maximum number of iterations, regularization values and features were set to default values. The output probability of presence of the species was set to logistic, and a threshold of the 10th percentile of training presence was used to generate binary layers. Finally, the binary maps of both models were superimposed by means of the program ArcMap v.9.3. The model performance was evaluated using the AUC and the threshold-dependent binomial omission tests calculated by Maxent.

\section{Results}

\subsection{Patterns of mitochondrial sequence variation and phylogeographic structure}

The resulting mitochondrial dataset contained 1988 bp of which 289 bp were variable and 245 parsimony-informative (excluding the outgroups). The phylogenetic tree resulting from the analysis of the mitochondrial data is presented in Fig. 2 and reveals five major haplotype clades with the following geographic delimitations (see Figs. 2 and 3): (1) Caspian clade, the basal-most split within the Bufo bufo species complex, corresponding to the species Bufo eichwaldi. It is distributed along the Southern shore of the Caspian Sea (Southeastern Azerbaijan and probably Iran); (2) European clade, corresponding to Bufo bufo sensu stricto (includes specimens from the type locality of Bufo bufo). According to Fig. 2 and Table 1, this clade appears to include specimens classified as both B. b. bufo and $B$. b. spinosus. It is the sister group to the Caucasian clade and is the clade with the largest distributional range, encompassing most of the currently known distribution of the species with the exception of Southern and Western France, Iberian Peninsula, North Africa and the Caucasus; (3) Caucasian clade, the sister group to the European clade, includes the taxon Bufo verrucosissimus and one population (locality 167 ) assigned to $B$. b. spinosus (Table 1 ). It is distributed across the Caucasus, with one population in Anatolia; (4) Iberian clade, distributed across the entire Iberian Peninsula and Southern and Western France, includes populations classified as $B$. b. spinosus and B. b. gredosicola; and (5) African clade, the sister group to the Iberian clade, includes specimens assigned to $B$. $b$. spinosus only and it is distributed across the mountain ranges and humid areas of Morocco, Algeria and Tunisia.

The average uncorrected sequence divergence ( $p$-distance) among these five major clades is $5.42 \%$. Table 2 shows the pairwise distances among clades for the 16S and ND1 genes.

As stated above, Bufo b. spinosus and B. b. bufo were not monophyletic in our analyses of the mtDNA data (Fig. 2 and Table 1). The results of both the $\mathrm{SH}$ and $\mathrm{AU}$ tests indicate that the best tree enforcing monophyly of the currently defined subspecies has significantly less likelihood $(P<0.0001)$ than the unconstrained ML topology shown in Fig. 2 ( $\log L_{\text {unconstrained }}=-7570.303$; $\log L_{\text {constrained }}=-8034.871$ ).

Regarding the shallow phylogenetic structure, the different clades show different degrees of intraclade structuring. The Iberian clade does not have a well-supported structure in either ML or BI analyses, and this structure lacks correlation with geography (Figs. 1 and 2). By contrast, the European, Caucasian and African clades show an explicit degree of geographic structuring in both ML and BI analyses. Indeed, in the European clade seven subclades are recovered in our analysis, corresponding to the following geographic regions (see Figs. 2 and 3): Southern Italy (e7), North-Central Italy (e6), Greek Peninsula (e5), North-Central Europe (e1), South-Central Europe (e3), Southwestern Europe (e2) and Anatolia (including Northeastern Greece) (e4). All of them have high pp and bootstrap support values with the only exception of the Anatolian clade (despite being recovered by both ML and Bayesian analyses).

In addition, the Caucasian clade is composed of three well-supported subclades: North Caucasus, South Caucasus and Central Anatolia (c1, c2 and c3 respectively), and the African clade includes two subclades, a Moroccan clade and a Tunisian clade (a1 and a2 respectively). The lack of sampling in Algeria hampers resolution 
and subspecies of the Bufo bufo species complex, with the only exception of $B$. $b$. gredosicola. Electrophoretic conditions for the proteins studied were as described by Litvinchuk et al. (2008). The populations of the Bufo bufo species complex included in the allozyme analysis are shown in Fig. 1, and the corresponding locality names and taxonomic assignment are presented in Table 1.

The software BIOSYS-1 (Swofford and Selander, 1981) was used to calculate the average expected and observed heterozygosity per locus (Hexp and Hobs), the percentage of polymorphic loci (P), as well as Nei's genetic distances (Nei, 1978). The matrix of Nei's genetic similarities was converted into a neighbor-joining tree (NJ; Saitou and Nei, 1987) using MEGA 5.0 (Tamura et al., 2011). This method of phylogenetic reconstruction is known to perform well for allozyme data (Wiens, 2000).

A Multiple Correspondence Analysis (MCA) on the population frequency data was performed with the computer software Statistica Kernel version 5.5 (StatSoft, Inc.; Tulsa; USA). For this analysis each row in the dataset was a population and each column represented the frequency of the $i$ th allele of the $j$ th locus.

\subsection{Dating estimates}

Divergence dates for our dataset were estimated using a Bayesian relaxed molecular clock approach (BRMC) by means of the package BEAST v. 1.5.2 (Drummond and Rambaut, 2007). Given that some priors (e.g. tree priors) do not adequately account simultaneously for both interspecific (phylogenetic priors) and intraspecific data (coalescent priors), we opted for a reduction of our dataset maintaining solely one representative of each clade as appeared in our ML phylogeny. In this way we also reduced the amount of intraspecific polymorphism, which yields an overestimation of the divergence times when deep and external calibration points are used (Ho et al., 2008).

In order to introduce the calibration points, all external to our ingroup, we included the Bufo bufo species complex in the phylogenetic context of 173 species belonging to the family Bufonidae (approximately $30 \%$ of the species of the family) plus six species that were used as outgroups (Supplementary material I and II).

Four external calibration points were used, all of them already employed in previous studies to calibrate timescales encompassing the whole family Bufonidae (Pramuk et al., 2007; Van Bocxlaer et al., 2009, 2010, see references therein) (Supplementary material II):

1. A soft maximum of $49 \mathrm{Ma}$ for the split between the Caribbean Bufonidae (genus Peltophryne) and their closest mainland relatives (genus Rhaebo). This calibration is based on the geological evidence implying that the existence of emerged land in the Caribbean Sea is not older than 37-49 Ma. The soft maximum was obtained by means of a lognormal distribution with a mean placed in $27 \mathrm{Ma}$, a standard deviation of 0.35 and an offset of $5 \mathrm{Ma}$.

2. The oldest fossil attributable to the family Bufonidae in North America (20 Ma), was used as a minimum age for the split between the North American toads (genus Anaxyurus) and their sister group, the Central-American toads of the genus Incilius. This was set using a gamma distribution (alpha $=1.2$, beta $=4$ ) starting at $20 \mathrm{Ma}$.

3. The oldest fossils belonging to the Bufotes viridis species complex, all dating from the Lower Miocene of Southeastern France, Greece, Northern Turkey and Southern Germany, are assumed in this study to belong to the lineage leading to the European Bufotes viridis complex, therefore representing a minimum age for the split between this lineage and the lineage leading to Bufotes surdus. The calibration point was associated to a Gamma distribution (alpha $=1.2$, beta $=4$ ) with an offset placed in $18 \mathrm{Ma}$.
4. The oldest fossil attributable to the Rhinella marina species complex (11 Ma), was established as a minimum age for the split between the Rhinella marina species complex and its sister group, the Rhinella granulosa species complex. This was set by means of a Gamma distribution (alpha $=1.2$, beta $=4$ ) with an offset established in $11 \mathrm{Ma}$.

Preliminary analyses showed that our mitochondrial markers (tRNAval, 16S and ND1) could not resolve deep nodes, so we concatenated two nuclear genes CXCR4 (688 pb) and NCX1 (1285 pb) downloaded from GenBank to improve the resolution of the deep splits (see Supplementary material I). The unalignable regions of the noncoding mitochondrial markers were removed by means of Gblocks (Castresana, 2000), eliminating the misaligned regions and the positions with more than $50 \%$ missing data (36\% of the original mitochondrial dataset).

A Yule branching process with a uniform prior and an uncorrelated branch rate variation was modeled by means of a resampling from a lognormal distribution. The model of evolution was set to GTRGAMMAI. The clock model and the evolutionary models were applied independently to the four partitions: (1) mitochondrial protein-coding; (2) mitochondrial RNA-coding; (3) nuclear CXCR4; and (4) nuclear NCX1 (Van Bocxlaer et al., 2009).

The analysis consisted of five independent Markov chain Monte Carlo (MCMC) analyses; each chain was run for 25,000,000 generations with parameters and trees sampled every 1000 generations. These five independent runs converged on very similar posterior estimates and were combined using LogCombiner version 1.4 after excluding the first 5,000,000 generations in each one (Rambaut and Drummond, 2007). Tracer 1.2 (Rambaut and Drummond, 2007) was used to confirm convergence and good mixing of the five combined MCMC chains. Finally we generated the maximum clade credibility consensus tree with median node heights using the TreeAnnotator program (also included in BEAST package), setting the posterior probability limit to 0.5 .

\subsection{Species distribution modeling}

Distribution models were used to tackle two questions: first, to test the role of the Central Asian Deserts as a biogeographic barrier; and secondly to examine whether the climate-based potential distribution of the species in the Last Glacial Maximum (LGM) could explain the shallow structure found in the most structured parts of our phylogeny.

\subsubsection{Testing the Central Asian Deserts as a biogeographic barrier}

Correlative distribution models can be very useful tools for testing the existence of environmental barriers to dispersal and gene flow, particularly when we suspect, as in this case, that the distribution limits can be greatly determined by climatic causes (the existence of the Central Asian Deserts) (Kozak et al., 2008; Sexton et al., 2009).

To accomplish this, we modeled the current distribution of both species complexes in Eurasia. The Bufo bufo species complex was modeled using the localities included in this study (168 localities) to which we added 269 georeferenced localities of the species complex in Russia and adjacent countries (unpublished data from SNL) plus 23,803 localities from its entire distribution range obtained from Gbif (http://data.gbif.org). To produce the distribution models of the Bufo gargarizans species complex, we downloaded from Gbif all available localities of Bufo tibetanus (511 localities), Bufo andrewsi (1959 localities), Bufo tuberculatus (9 localities), Bufo cryptotympanicus (4 localities) and Bufo gargarizans (787 localities). The localities belonging to Bufo japonicus (18 localities) were obtained from Igawa et al. (2006). 


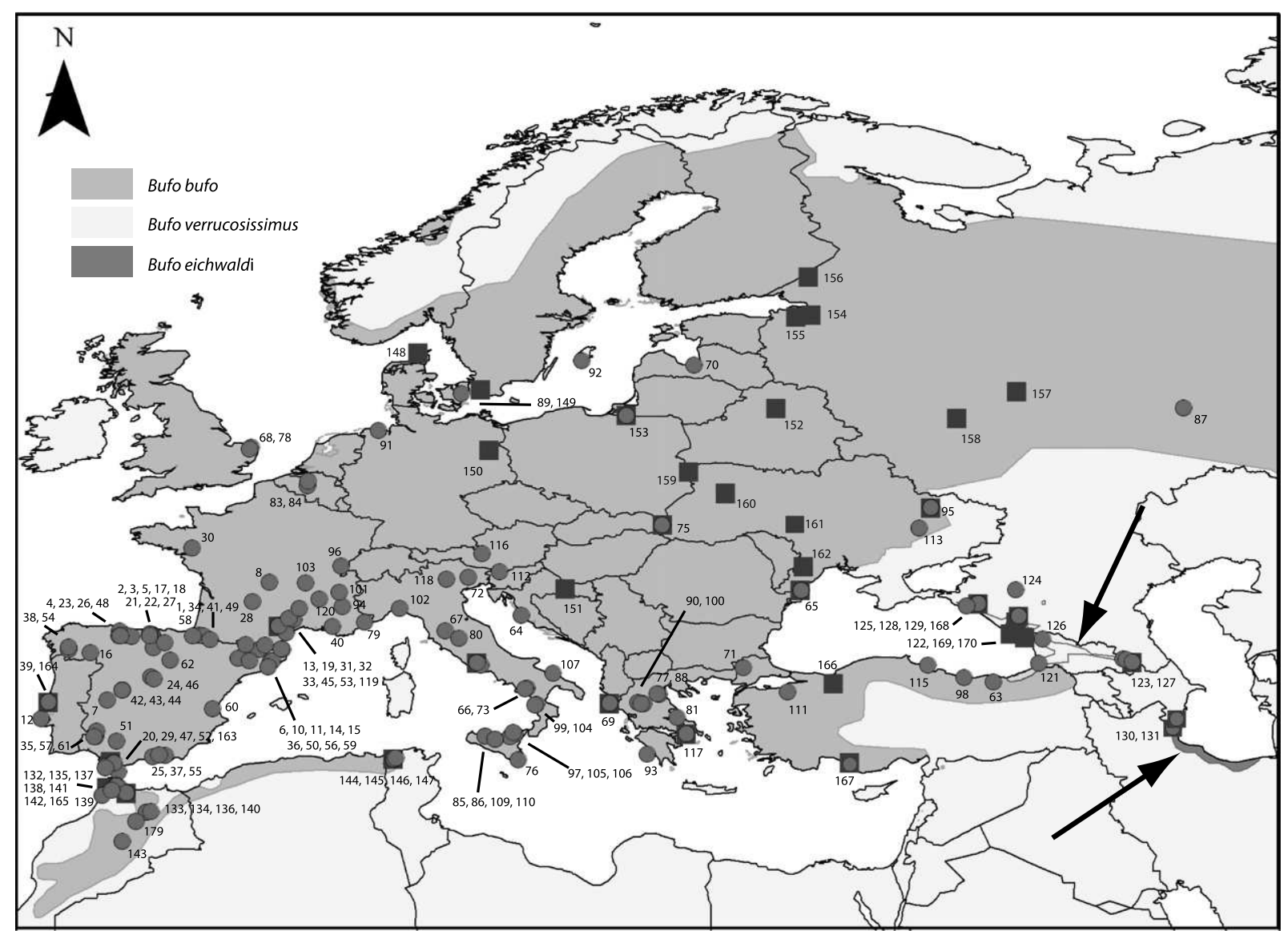

Fig. 1. Sampling localities included in the present study. Red circles indicate DNA sampling localities; blue squares indicate allozyme sampling localities. The background colors indicate the known distribution of Bufo bufo (green), Bufo verrucosissimus (yellow) and Bufo eichwaldi (purple). Map numbers refer to specimens listed in Table 1 and Fig. 2. Arrows highlight the distribution ranges of B. verrucosissimus and B. eichwaldi. (For interpretation of the references to color in this figure legend, the reader is referred to the web version of this article.)

for the ML and Bayesian analyses under Akaike's information criterion. This was the GTR model taking into account the gamma distribution and the number of invariant sites for each of the two independent partitions. To explore the topological space, we performed 1000 independent heuristic searches each one starting from a parsimony tree. The likelihoods of the resulting trees of each run were compared and the one with the highest $-\log L$ was selected. Reliability of the ML searches was assessed by bootstrap analysis (Felsenstein, 1985), involving 1000 replications. Support values for every node were superimposed onto the best tree topology.

BI analysis was conducted using MrBayes 3.1.2 (Ronquist and Huelsenbeck, 2003). The dataset was split into the same two partitions mentioned before (protein-coding and RNA-coding mitochondrial regions) and two independent runs of four Markov chain Monte Carlo (MCMC) chains were executed in parallel for 10 million generations, with a sampling interval of 1000 generations. Preliminary analyses (data not shown) revealed that our dataset was extremely sensitive to the branch-length prior, producing trees with very long branches (several orders of magnitude longer than the branches of the ML tree). This is not a rare phenomenon, which has been reviewed and analyzed in several recent papers (e.g. Brown et al., 2010; Marshall, 2010). To solve this problem, we followed the recommendations by Brown et al. (2010) and specified a branch-length prior with a smaller mean to reduce the posterior probability of the long-tree region in the branch-length space. The new mean was calculated using the formula proposed by the authors and was set to $1 / 379$. Convergence of the two runs was evidenced by a split frequency standard devi- ation lower than 0.01 and by potential scale-reduction factors to 1 for all model parameters as shown by the command "sump" in MrBayes (Ronquist and Huelsenbeck, 2003). Posterior probabilities (pp) for every clade were obtained by combining the sampled trees from the two parallel runs excluding a relative burn-in of $30 \%$ of the trees from each run. In both analyses three species of the Bufo gargarizans species complex were used to root the tree (Bufo gargarizans, Bufo japonicus and Bufo andrewsi).

To determine whether the mtDNA data supported the currently established taxonomic partitions proposed by Mertens and Wermuth (1960), we used topological constraints to enforce monophyly of the subspecies as currently defined (see Table 1), using the package Mesquite v2.78 (Maddison and Maddison, 2009). Topological constraints were compared to optimal topologies using the Approximately-Unbiased (AU) (Shimodaira, 2002) and Shimodaira-Hassegawa tests implemented in CONSEL (Shimodaira and Hasegawa, 2001). The subspecies were assigned to our specimens following Mertens and Wermuth (1960), Lizana (2002) and Muratet (2008) and on information on the morphological variation of the species (PAC and PG, unpublished results). The specimens of dubious taxonomic assignment were excluded from the test.

\subsection{Allozymes}

Sixteen protein systems, corresponding to 21 presumptive loci were examined for 172 specimens from 40 different localities, including Bufo gargarizans and representatives from all the species 


\begin{tabular}{|c|c|c|c|c|c|c|c|c|c|c|c|}
\hline 122 & $\begin{array}{l}\text { DNA/ } \\
\text { allozymes }\end{array}$ & 44.0833 & 40.7667 & Psebai & Russia & B. verrucosissimus & Caucasian & ZISP.6547 & JQ348647 & JQ348792 & JQ348424 \\
\hline 123 & DNA & 41.8262 & 46.2697 & Lagodekhi & Georgia & B. verrucosissimus & Caucasian & ZISP.4963 & JQ348645 & JQ348790 & JQ348417 \\
\hline 124 & DNA & 45.4167 & 40.6167 & Kyurdzhinovo & Russia & B. verrucosissimus & Caucasian & ZISP.6541 & JQ348619 & JQ348764 & JQ348420 \\
\hline 125 & $\begin{array}{l}\text { DNA/ } \\
\text { allozymes }\end{array}$ & 44.7167 & 38.6833 & Krepostnaya & Russia & B. verrucosissimus & Caucasian & & JQ348662 & JQ348807 & JQ348425 \\
\hline 126 & DNA & 42.9053 & 41.9833 & Katkova & Georgia & B. verrucosissimus & Caucasian & & JQ348670 & JQ348815 & JQ348423 \\
\hline 127 & $\begin{array}{l}\text { DNA/ } \\
\text { allozymes }\end{array}$ & 41.7167 & 46.6 & Katekh & Azerbaijan & B. verrucosissimus & Caucasian & & JQ348674 & JQ348819 & JQ348418 \\
\hline 128 & DNA & 44.83 & 40.20 & Guzeripl & Russia & B. verrucosissimus & Caucasian & ZISP.6614 & JQ348669 & JQ348814 & JQ348421 \\
\hline 129 & DNA & 44.5777 & 38.0802 & Gelenjik & Russia & B. verrucosissimus & Caucasian & & JQ348646 & JQ348791 & JQ348422 \\
\hline 130 & $\begin{array}{l}\text { DNA/ } \\
\text { allozymes }\end{array}$ & 38.45 & 48.73 & Sim & Azerbaijan & B. eichwaldi & Caspian & & JQ348681 & JQ348826 & JQ348546 \\
\hline 131 & $\begin{array}{l}\text { DNA/ } \\
\text { allozymes }\end{array}$ & 38.65 & 48.8 & Avrora & Azerbaijan & B. eichwaldi & Caspian & ZISP.7185 & JQ348680 & JQ348825 & JQ348545 \\
\hline 132 & DNA & 35.3689 & -5.5402 & Zinat & Morocco & B. b. spinosus & African & & JQ348614 & JQ348757 & JQ348541 \\
\hline 133 & DNA & 34 & -4 & Tazeka 1 & Morocco & B. b. spinosus & African & & JQ348608 & JQ348751 & JQ348535 \\
\hline 134 & DNA & 34 & -4 & Tazeka 2 & Morocco & B. b. spinosus & African & & JQ348609 & JQ348752 & JQ348536 \\
\hline 135 & DNA & 35.0706 & -5.1742 & $\begin{array}{l}3 \mathrm{~km} \text { NE of Bab } \\
\text { Taza }\end{array}$ & Morocco & B. b. spinosus & African & & JQ348615 & JQ348758 & JQ348537 \\
\hline 136 & DNA & 33.5161 & -4.5322 & Skoura M’daz & Morocco & B. b. spinosus & African & & JQ348613 & JQ348756 & JQ348539 \\
\hline 137 & DNA & 35.2801 & -5.4018 & $\begin{array}{l}\text { Souk-el-Arba- } \\
\text { des-Beni-Hassan }\end{array}$ & Morocco & B. b. spinosus & African & & JQ348612 & JQ348755 & JQ348544 \\
\hline 138 & DNA & 35.3335 & -5.5382 & Moulay Abdeslam & Morocco & B. b. spinosus & African & & JQ348611 & JQ348754 & JQ348542 \\
\hline 139 & DNA & 34.8759 & -6.2495 & Merja Zerga & Morocco & B. b. spinosus & African & & JQ348617 & JQ348760 & JQ348540 \\
\hline 140 & DNA & 34.05 & -3.7667 & Ifrane & Morocco & B. b. spinosus & African & & JQ348618 & JQ348761 & JQ348538 \\
\hline 141 & $\begin{array}{l}\text { DNA/ } \\
\text { allozymes }\end{array}$ & 34.95 & -5.23 & Fifi & Morocco & B. b. spinosus & African & & JQ348607 & JQ348750 & JQ348533 \\
\hline 142 & DNA & 35.1242 & -5.7749 & $\begin{array}{l}3 \mathrm{~km} \mathrm{~W} \text { of } \\
\text { Hamaïmoun }\end{array}$ & Morocco & B. b. spinosus & African & & JQ348610 & JQ348753 & JQ348534 \\
\hline 143 & DNA & 32.4908 & -5.2347 & Tounfite & Morocco & B. b. spinosus & African & & JQ348616 & JQ348759 & JQ348543 \\
\hline 144 & $\begin{array}{l}\text { DNA/ } \\
\text { allozymes }\end{array}$ & 36.7304 & 8.7080 & Ain Draham 1 & Tunisia & B. b. spinosus & African & ZISP.7523 & JQ348603 & JQ348746 & JQ348532 \\
\hline 145 & DNA & 36.776 & 8.6917 & Ain Draham 2 & Tunisia & B. b. spinosus & African & & JQ348606 & JQ348749 & JQ348531 \\
\hline 146 & DNA & 36.7304 & 8.7080 & Ain Draham 3 & Tunisia & B. b. spinosus & African & & JQ348605 & JQ348748 & \\
\hline 147 & DNA & 36.7801 & 8.8183 & Ain Draham 4 & Tunisia & B. b. spinosus & African & & JQ348604 & JQ348747 & JQ348530 \\
\hline 148 & Allozymes & 57.5833 & 9.9667 & Hirtshals & Denmark & B. b. bufo & European & $\begin{array}{l}\text { ZISP.8525- } \\
8526\end{array}$ & & & \\
\hline 149 & Allozymes & 55.6833 & 13.1667 & Lund & Sweden & B. b. bufo & European & & & & \\
\hline 150 & Allozymes & 52.6000 & 13.6167 & Blumberg & Germany & B. b. bufo & European & & & & \\
\hline 151 & Allozymes & 45.5000 & 17.5167 & $\begin{array}{l}1.5 \mathrm{~km} \mathrm{~N} \text { of } \\
\text { Mrkoplje }\end{array}$ & Croatia & B. b. spinosus & European & & & & \\
\hline 152 & Allozymes & 54.7333 & 28.3333 & Domzheritsy & Byelorussia & B. b. bufo & European & & & & \\
\hline 153 & $\begin{array}{l}\text { DNA/ } \\
\text { allozymes }\end{array}$ & 54.38 & 20.64 & Bagrationovsk & Russia & B. b. bufo & European & ZISP.7048 & JQ348639 & JQ348784 & JQ348439 \\
\hline 154 & Allozymes & 59.56 & 30.12 & Gatchina & Russia & B. b. bufo & European & $\begin{array}{l}\text { ZISP.6992, } \\
\text { 7259, } 7508\end{array}$ & & & \\
\hline 155 & Allozymes & 59.45 & 29.37 & $6 \mathrm{~km} \mathrm{~W}$ Volosovo & Russia & B. b. bufo & European & & & & \\
\hline 156 & Allozymes & 61.50 & 29.98 & Ikhala & Russia & B. b. bufo & European & & & & \\
\hline 157 & Allozymes & 55.60 & 40.67 & Gus-Khrustalnyi & Russia & B. b. bufo & European & & & & \\
\hline 158 & Allozymes & 54.2167 & 37.6167 & Tula & Russia & B. b. bufo & European & & & & \\
\hline 159 & Allozymes & 51.48 & 23.85 & Svityaz' & Ukraine & B. b. bufo & European & & & & \\
\hline 160 & Allozymes & 50.43 & 25.74 & Dubno & Ukraine & B. b. bufo & European & & & & \\
\hline 161 & Allozymes & 48.7833 & 29.5167 & Chechelivka & Ukraine & B. b. bufo & European & & & & \\
\hline 162 & Allozymes & 46.65 & 29.75 & Laptura Lake & Moldavia & B. b. bufo & European & & & & \\
\hline 163 & Allozymes & 36.6948 & -5.7733 & San Jose del Valle & Spain & B. b. spinosus & Iberian & & & & \\
\hline 165 & Allozymes & 35.4920 & -5.8227 & $\begin{array}{l}5 \mathrm{~km} \mathrm{NE} \text { of } \\
\text { Charkia }\end{array}$ & Morocco & B. b. spinosus & African & & & & \\
\hline 166 & Allozymes & 40.6167 & 31.2833 & Abant Lake & Turkey & B. b. spinosus & Caucasian & $\begin{array}{l}\text { ZISP.8101- } \\
8103\end{array}$ & & & \\
\hline 167 & $\begin{array}{l}\text { DNA/ } \\
\text { allozymes }\end{array}$ & 36.55 & 32.1167 & Alanya & Turkey & B. b. spinosus & Caucasian & & JQ348666 & JQ348811 & JQ348419 \\
\hline 168 & Allozymes & 42.98 & 41.10 & Bagmaran & Abkhazia & B. verrucosissimus & Caucasian & & & & \\
\hline 169 & Allozymes & 43.17 & 40.35 & Lidzava & Abkhazia & B. verrucosissimus & Caucasian & & & & \\
\hline 170 & Allozymes & 43.80 & 40.65 & Nikitino & Russia & B. verrucosissimus & Caucasian & & & & \\
\hline \multicolumn{12}{|c|}{ OUTGROUPS } \\
\hline Spec & & & \multicolumn{3}{|l|}{ Locality } & \multicolumn{2}{|l|}{ Country } & \multicolumn{2}{|c|}{ Data Type } & \multicolumn{2}{|c|}{ GenBank ref } \\
\hline \multicolumn{2}{|c|}{ B. gargarizans } & & \multicolumn{3}{|c|}{ Chusan Island } & \multicolumn{2}{|l|}{ China } & \multicolumn{2}{|l|}{ DNA } & \multicolumn{2}{|c|}{ NC008410.1 } \\
\hline \multicolumn{2}{|c|}{ B. gargarizans } & & \multicolumn{3}{|c|}{ Song } & \multicolumn{2}{|l|}{ China } & \multicolumn{2}{|l|}{ DNA } & FJ\& & 843.1 \\
\hline B. $g a$ & & & Bonevurov & & & Russia & & allozy & & & ymes - 171 \\
\hline B. $g a$ & & & Krym & & & Russia & & allozy & & & ymes - 172 \\
\hline B. $g a$ & & & Novoaleksa & drovsk (Sakhalin Isla & and) & Russia & & allozy & & & ymes - 173 \\
\hline B. $g a$ & & & Quingchen & Mt. (Sichuan Proving & & China & & allozy & & & ymes - 174 \\
\hline B. jal & & & Hiroshima & & & Japan & & DNA & & & 9886.1 \\
\hline B. an & & & Yunnan & & & China & & DNA & & & 808 \\
\hline
\end{tabular}


Table 1 (continued)

\begin{tabular}{|c|c|c|c|c|c|c|c|c|c|c|c|}
\hline $\begin{array}{l}\text { Specimen } \\
\text { number }\end{array}$ & Data Type & Latitude & Longitude & Locality & Country & Taxon & $\begin{array}{l}\text { Clade/ } \\
\text { MCA } \\
\text { group }\end{array}$ & VOUCHER & $\begin{array}{l}\text { GenBankt } \\
\text { RNA-16S } \\
1^{\text {st }} \text { part }\end{array}$ & $\begin{array}{l}\text { GenBank16S } \\
2^{\text {nd }} \text { part }\end{array}$ & $\begin{array}{l}\text { GenBank } \\
\text { ND1 }\end{array}$ \\
\hline 57 & DNA & 38.1479 & -6.5601 & $\begin{array}{l}\text { Bodonal de la } \\
\text { Sierra }\end{array}$ & Spain & B. b. spinosus & Iberian & & JQ348572 & JQ348715 & JQ348518 \\
\hline 58 & DNA & 43.0490 & -1.6145 & Puerto de Belate & Spain & B. b. bufo & Iberian & & JQ348561 & JQ348704 & JQ348487 \\
\hline 59 & DNA & 41.4501 & 2.2474 & Badalona & Spain & B. b. spinosus & Iberian & & JQ348552 & JQ348695 & JQ348477 \\
\hline 60 & DNA & 39.3037 & -0.5859 & Catadau & Spain & B. b. spinosus & Iberian & BEV.7287 & JQ348598 & JQ348741 & JQ348514 \\
\hline 61 & DNA & 37.8744 & -6.6661 & Alajar & Spain & B. b. spinosus & Iberian & & JQ348571 & JQ348714 & JQ348526 \\
\hline 62 & DNA & 41.8077 & -2.7856 & Abejar & Spain & B. b. spinosus & Iberian & & JQ348570 & JQ348713 & JQ348517 \\
\hline 63 & DNA & 40.6996 & 39.4678 & Anayurt & Turkey & B. b. spinosus & European & $\begin{array}{l}\text { BEV.7627- } \\
7628\end{array}$ & JQ348659 & JQ348804 & JQ348447 \\
\hline 64 & DNA & 44.1167 & 15.2333 & Zadar & Croatia & B. b. spinosus & European & & JQ348657 & JQ348802 & JQ348456 \\
\hline 65 & $\begin{array}{l}\text { DNA/ } \\
\text { allozymes }\end{array}$ & 45.400 & 29.600 & Vilkovo & Ukraine & B. b. bufo & European & & JQ348660 & JQ348805 & JQ348469 \\
\hline 66 & DNA & 40.3796 & 15.5310 & Teggiano & Italy & B. b. spinosus & European & & JQ348648 & JQ348793 & JQ348466 \\
\hline 67 & DNA & 43.3187 & 11.3305 & Siena & Italy & B. b. spinosus & European & & JQ348667 & JQ348812 & JQ348436 \\
\hline 68 & DNA & 52.7066 & 1.3993 & Wroxham & UK & B. b. bufo & European & & JQ348661 & JQ348806 & JQ348445 \\
\hline 69 & $\begin{array}{l}\text { DNA/ } \\
\text { allozymes }\end{array}$ & 39.6167 & 19.7833 & $\begin{array}{l}\text { Ropa, Kerkira } \\
\text { island }\end{array}$ & Greece & B. b. spinosus & European & & JQ348668 & JQ348813 & JQ348432 \\
\hline 70 & DNA & 56.9465 & 24.1048 & Riga & Latvia & B. b. bufo & European & & AY325988 & & \\
\hline 71 & DNA & 41.4135 & 26.6289 & Pythio & Greece & B. b. spinosus & European & & JQ348658 & JQ348803 & JQ348446 \\
\hline 72 & DNA & 46.0808 & 12.5378 & Piancavallo & Italy & B. b. spinosus & European & & JQ348622 & JQ348767 & JQ348458 \\
\hline 73 & DNA & 40.3490 & 15.4383 & Piaggine & Italy & B. b. spinosus & European & & JQ348649 & JQ348794 & JQ348463 \\
\hline 75 & DNA & 48.7406 & 22.4890 & Perechin & Ukraine & B. b. bufo & European & & JQ348636 & JQ348781 & JQ348438 \\
\hline 76 & DNA & 36.6910 & 15.0692 & Pachino & Italy & B. b. spinosus & European & & JQ348654 & JQ348799 & JQ348474 \\
\hline 77 & DNA & 40.0436 & 22.3002 & Olympus mt. & Greece & B. b. spinosus & European & & JQ348627 & JQ348772 & JQ348431 \\
\hline 78 & DNA & 52.6281 & 1.2993 & Norwich & UK & B. b. bufo & European & & JQ348632 & JQ348777 & \\
\hline 79 & DNA & 43.7734 & 7.2241 & Nice & France & B. b. spinosus & European & BEV.T2997 & JQ348683 & & JQ348452 \\
\hline 80 & DNA & 42.9244 & 12.0579 & $\begin{array}{l}\text { Monteleone } \\
\text { d'Orvieto }\end{array}$ & Italy & B. b. spinosus & European & & JQ348643 & JQ348788 & JQ348434 \\
\hline 81 & DNA & 38.8723 & 23.2389 & Marouli & Greece & B. b. spinosus & European & & JQ348631 & JQ348776 & JQ348430 \\
\hline 82 & DNA & 41.5516 & 13.1711 & Maenza & Italy & B. b. spinosus & European & & JQ348640 & JQ348785 & JQ348433 \\
\hline 83 & DNA & 50.7635 & 4.27931 & Lot & Belgium & B. b. bufo & European & & JQ348665 & JQ348810 & JQ348470 \\
\hline 84 & DNA & 51.0020 & 4.3019 & Londerzeel & Belgium & B. b. bufo & European & & FJ882806 & & \\
\hline 85 & DNA & 37.9208 & 13.3732 & Lago Scanzano 1 & Italy & B. b. spinosus & European & & JQ348651 & JQ348796 & JQ348460 \\
\hline 86 & DNA & 37.9208 & 13.3732 & Lago Scanzano 2 & Italy & B. b. spinosus & European & & JQ348653 & JQ348798 & JQ348472 \\
\hline 87 & DNA & 54.7333 & 49.2333 & Kokryad & Russia & B. b. bufo & European & & JQ348637 & JQ348782 & JQ348440 \\
\hline 88 & DNA & 40.0764 & 22.2269 & Kokkinopilos & Greece & B. b. spinosus & European & & JQ348625 & JQ348770 & JQ348426 \\
\hline 89 & DNA & 55.4580 & 12.1821 & Køge & Denmark & B. b. bufo & European & & JQ348635 & JQ348780 & JQ348437 \\
\hline 90 & DNA & 39.6358 & 21.2182 & Katafyto & Greece & B. b. spinosus & European & & JQ348628 & JQ348773 & JQ348428 \\
\hline 91 & DNA & 53.5757 & 7.9003 & Jever & Germany & B. b. bufo & European & & JQ348633 & JQ348778 & \\
\hline 92 & DNA & 57.1601 & 18.3362 & $\begin{array}{l}\text { Havdhem, } \\
\text { Gotland }\end{array}$ & Sweden & B. b. bufo & European & BEV.7720 & JQ348634 & JQ348779 & \\
\hline 93 & DNA & 36.9664 & 21.6989 & Gialova & Greece & B. b. spinosus & European & & JQ348626 & JQ348771 & JQ348427 \\
\hline 94 & DNA & 44.5769 & 6.0532 & Gap & France & B. b. spinosus & European & BEV.1259 & JQ348672 & JQ348817 & JQ348443 \\
\hline 95 & $\begin{array}{l}\text { DNA/ } \\
\text { allozymes }\end{array}$ & 49.65 & 36.26 & Haidary & Ukraine & B. b. bufo & European & ZISP.7282 & JQ348673 & JQ348818 & JQ348442 \\
\hline 96 & DNA & 46.6468 & 6.0088 & Foncine-le-Bas & France & B. b. bufo & European & BEV.8928 & JQ348675 & JQ348820 & JQ348455 \\
\hline 97 & DNA & 37.9871 & 14.9083 & Floresta & Italy & B. b. spinosus & European & & JQ348656 & JQ348801 & JQ348462 \\
\hline 98 & DNA & 40.9272 & 37.9523 & Kayabaşı & Turkey & B. b. spinosus & European & BEV.7656 & JQ348679 & JQ348824 & JQ348449 \\
\hline 99 & DNA & 39.5528 & 16.0222 & $\begin{array}{l}\text { Lago dei Due } \\
\text { Uomini }\end{array}$ & Italy & B. b. spinosus & European & & JQ348655 & JQ348800 & JQ348465 \\
\hline 100 & DNA & 39.5604 & 21.3719 & Desi & Greece & B. b. spinosus & European & & JQ348630 & JQ348775 & JQ348429 \\
\hline 101 & DNA & 45.2868 & 5.9067 & Crolles & France & ambiguous & European & BEV.T2998 & JQ348623 & JQ348768 & JQ348451 \\
\hline 102 & DNA & 44.4722 & 9.0083 & Creto & Italy & B. b. spinosus & European & & JQ348642 & JQ348787 & JQ348471 \\
\hline 103 & DNA & 45.7725 & 4.1759 & Cleppé & France & B. b. spinosus & European & BEV.10226 & JQ348624 & JQ348769 & \\
\hline 104 & DNA & 39.5167 & 15.9500 & Cetraro & Italy & B. b. spinosus & European & & JQ348686 & JQ348763 & JQ348464 \\
\hline 105 & DNA & 37.8835 & 14.6564 & Cesaro & Italy & B. b. spinosus & European & & JQ348652 & JQ348797 & JQ348461 \\
\hline 106 & DNA & 38.0825 & 14.8162 & Castell’Umberto & Italy & B. b. spinosus & European & & JQ348676 & JQ348821 & JQ348473 \\
\hline 107 & DNA & 41.1260 & 16.8693 & Bari & Italy & B. b. spinosus & European & & JQ348650 & JQ348795 & JQ348467 \\
\hline 108 & $\begin{array}{l}\text { DNA/ } \\
\text { allozymes }\end{array}$ & 41.6667 & 12.9833 & Campa di Segni & Italy & B. b. spinosus & European & ZISP.9534 & JQ348641 & JQ348786 & JQ348435 \\
\hline 109 & DNA & 37.7597 & 13.8930 & Caltavuturo 1 & Italy & B. b. spinosus & European & & JQ348685 & JQ348762 & JQ348459 \\
\hline 110 & DNA & 37.7597 & 13.8930 & Caltavuturo 2 & Italy & B. b. spinosus & European & & JQ348678 & JQ348823 & JQ348468 \\
\hline 111 & DNA & 40.1833 & 28.8905 & Bursa & Turkey & B. b. spinosus & European & & DQ158438 & & \\
\hline 112 & DNA & 46.3667 & 14.1085 & Bled & Slovenia & ambiguous & European & & JQ348664 & JQ348809 & JQ348450 \\
\hline 113 & DNA & 48.6 & 35.6 & Balakhovka & Ukraine & B. b. bufo & European & & JQ348638 & JQ348783 & JQ348441 \\
\hline 115 & DNA & 41.5548 & 36.1127 & Bafra & Turkey & B. b. spinosus & European & BEV.7635 & JQ348671 & JQ348816 & JQ348448 \\
\hline 116 & DNA & 47.2802 & 13.2313 & $\mathrm{Au}$ & Austria & B. b. bufo & European & & JQ348620 & JQ348765 & JQ348453 \\
\hline 117 & $\begin{array}{l}\text { DNA/ } \\
\text { allozymes }\end{array}$ & 38.0333 & 23.7167 & Athens & Greece & B. b. spinosus & European & & JQ348629 & JQ348774 & JQ348475 \\
\hline 118 & DNA & 45.9675 & 11.4142 & Asiago & Italy & ambiguous & European & & JQ348621 & JQ348766 & JQ348457 \\
\hline 119 & DNA & 44.4742 & 3.8612 & Altier & France & B. b. spinosus & European & BEV.10238 & JQ348677 & JQ348822 & JQ348444 \\
\hline 120 & DNA & 44.9298 & 4.8899 & Valence & France & B. b. spinosus & European & & JQ348663 & JQ348808 & JQ348454 \\
\hline 121 & DNA & 41.65 & 41.80 & Tirala Mt. & Russia & B. verrucosissimus & Caucasian & ZISP.6534 & JQ348644 & JQ348789 & JQ348416 \\
\hline
\end{tabular}


Table 1

Sampling localities for the mitochondrial phylogeny and allozyme analysis (including geographic coordinates and country), taxonomic assignation and clade or group assignation according to the molecular phylogeny or the MCA analysis, respectively. A map with the geographic distribution of all the representatives of the Bufo bufo species complex included in our analyses is shown in Fig. 1.

\begin{tabular}{|c|c|c|c|c|c|c|c|c|c|c|c|}
\hline $\begin{array}{l}\text { Specimen } \\
\text { number }\end{array}$ & Data Type & Latitude & Longitude & Locality & Country & Taxon & $\begin{array}{l}\text { Clade/ } \\
\text { MCA } \\
\text { group }\end{array}$ & VOUCHER & $\begin{array}{l}\text { GenBankt } \\
\text { RNA-16S } \\
1^{\text {st }} \text { part }\end{array}$ & $\begin{array}{l}\text { GenBank16S } \\
2^{\text {nd }} \text { part }\end{array}$ & $\begin{array}{l}\text { GenBank } \\
\text { ND1 }\end{array}$ \\
\hline 1 & DNA & 42.42139 & -3.6445 & Zuriza & Spain & B. b. bufo & Iberian & & JQ348599 & JQ348742 & JQ348501 \\
\hline 2 & DNA & 43.1224 & -3.7149 & Vega de Pas 1 & Spain & B. b. bufo & Iberian & & JQ348581 & JQ348724 & JQ348497 \\
\hline 3 & DNA & 43.1272 & -3.7263 & Vega de Pas 2 & Spain & B. b. bufo & Iberian & & JQ348585 & JQ348728 & JQ348527 \\
\hline 4 & DNA & 43.3202 & -5.3521 & Valle del Tendi & Spain & B. b. bufo & Iberian & & JQ348563 & JQ348706 & JQ348500 \\
\hline 5 & DNA & 42.4514 & -3.6450 & Udiema river & Spain & ambiguous & Iberian & & JQ348550 & JQ348693 & JQ348524 \\
\hline 6 & DNA & 42.3414 & 1.7586 & Torrent del Pi & Spain & B. b. spinosus & Iberian & & JQ348556 & JQ348699 & JQ348529 \\
\hline 7 & DNA & 39.7717 & -6.0143 & Torrejon el Rubio & Spain & B. b. spinosus & Iberian & & FJ882841 & & \\
\hline 8 & DNA & 45.8162 & 2.3252 & Tigouleix & France & B. b. spinosus & Iberian & & & JQ348687 & \\
\hline 9 & DNA & 41.9215 & 0.7185 & Tartareu & Spain & B. b. spinosus & Iberian & & JQ348560 & JQ348703 & JQ348486 \\
\hline 10 & DNA & 42.3686 & 2.9807 & $\begin{array}{l}\text { St. Climent } \\
\text { Sescebes }\end{array}$ & Spain & B. b. spinosus & Iberian & & JQ348596 & JQ348739 & JQ348485 \\
\hline 11 & DNA & 42.6253 & 1.0864 & Son & Spain & B. b. bufo & Iberian & & JQ348573 & JQ348716 & JQ348528 \\
\hline 12 & DNA & 38.7985 & -9.3881 & Sintra & Portugal & B. b. spinosus & Iberian & & JQ348558 & JQ348701 & JQ348506 \\
\hline 13 & DNA & 43.7206 & 3.1517 & Serieys & France & B. b. spinosus & Iberian & & JQ348602 & JQ348745 & \\
\hline 14 & DNA & 41.7600 & 2.3949 & Montseny 1 & Spain & B. b. spinosus & Iberian & & JQ348549 & JQ348692 & JQ348522 \\
\hline 15 & DNA & 41.7686 & 2.4699 & Montseny 2 & Spain & B. b. spinosus & Iberian & & JQ348575 & JQ348718 & JQ348478 \\
\hline 16 & DNA & 42.1858 & -6.8684 & Sanabria & Spain & B. b. spinosus & Iberian & & JQ348559 & JQ348702 & JQ348503 \\
\hline 17 & DNA & 43.1565 & -3.8213 & $\begin{array}{l}\text { San Pedro del } \\
\text { Romeral } 1\end{array}$ & Spain & B. b. spinosus & Iberian & & JQ348579 & JQ348722 & JQ348491 \\
\hline 18 & DNA & 43.1565 & -3.8213 & $\begin{array}{l}\text { San Pedro del } \\
\text { Romeral } 2\end{array}$ & Spain & B. b. spinosus & Iberian & & JQ348580 & JQ348723 & JQ348496 \\
\hline 19 & DNA & 43.8600 & 3.3807 & Saint-Michel & France & B. b. spinosus & Iberian & $\begin{array}{l}\text { BEV.1271- } \\
1272\end{array}$ & JQ348547 & JQ348690 & JQ348481 \\
\hline 20 & DNA & 36.0917 & -5.4455 & Riogetares & Spain & B. b. spinosus & Iberian & & JQ348564 & JQ348707 & JQ348507 \\
\hline 21 & DNA & 43.0995 & -5.0109 & Retuerto & Spain & B. b. bufo & Iberian & & JQ348582 & JQ348725 & JQ348492 \\
\hline 22 & DNA & 42.7154 & -3.0592 & $\begin{array}{l}\text { Santa Gadea del } \\
\text { Cid }\end{array}$ & Spain & B. b. spinosus & Iberian & & JQ348562 & JQ348705 & JQ348488 \\
\hline 23 & DNA & 43.0646 & -5.3884 & $\begin{array}{l}\text { Puerto de San } \\
\text { Isidro }\end{array}$ & Spain & B. b. spinosus & Iberian & & JQ348590 & JQ348733 & JQ348490 \\
\hline 24 & DNA & 40.9468 & -3.7600 & $\begin{array}{l}\text { Puerto de } \\
\text { Navacerrada }\end{array}$ & Spain & B. b. spinosus & Iberian & & JQ348591 & JQ348734 & JQ348516 \\
\hline 25 & DNA & 36.9166 & -3.0423 & Darrical & Spain & B. b. spinosus & Iberian & & JQ348565 & JQ348708 & JQ348515 \\
\hline 26 & DNA & 43.0107 & -4.7463 & Pozo de las Lomas & Spain & B. b. bufo & Iberian & & JQ348600 & JQ348743 & JQ348523 \\
\hline 27 & DNA & 43.0567 & -3.8412 & Penilla & Spain & B. b. spinosus & Iberian & & JQ348583 & JQ348726 & JQ348493 \\
\hline 28 & DNA & 44.8064 & 1.4554 & Payrac & France & B. b. spinosus & Iberian & BEV.680 & JQ348555 & JQ348698 & JQ348483 \\
\hline 29 & DNA & 36.3649 & -6.0718 & Pago del Humo & Spain & B. b. spinosus & Iberian & & JQ348567 & JQ348710 & JQ348525 \\
\hline 30 & DNA & 47.5543 & -1.6529 & Nozay & France & B. b. spinosus & Iberian & & JQ348601 & JQ348744 & JQ348504 \\
\hline 31 & DNA & 43.5755 & 3.7195 & $\begin{array}{l}\text { Murviel-lès- } \\
\text { Montpellier }\end{array}$ & France & B. b. spinosus & Iberian & BEV.682 & & & JQ348415 \\
\hline 32 & DNA & 43.2275 & 3.1938 & Mire l'Etang & France & B. b. spinosus & Iberian & BEV.8851 & JQ348684 & JQ348689 & \\
\hline 33 & DNA & 43.8867 & 3.5680 & Rogues & France & B. b. spinosus & Iberian & BEV.1456 & & JQ348688 & \\
\hline 34 & DNA & 43.0897 & -1.3034 & Luzaide & Spain & ambiguous & Iberian & & JQ348589 & JQ348732 & JQ348499 \\
\hline 35 & DNA & 37.8801 & -6.6210 & $\begin{array}{l}\text { Linares de la } \\
\text { Sierra }\end{array}$ & Spain & B. b. spinosus & Iberian & & JQ348557 & JQ348700 & JQ348505 \\
\hline 36 & DNA & 42.5652 & 2.1004 & Les Angles & France & B. b. spinosus & Iberian & & JQ348595 & JQ348738 & JQ348479 \\
\hline 37 & DNA & 36.8343 & -3.6744 & Lentegi & Spain & B. b. spinosus & Iberian & & JQ348568 & JQ348711 & JQ348520 \\
\hline 38 & DNA & 42.3693 & -8.000 & Punxin & Spain & ambiguous & Iberian & & JQ348577 & JQ348720 & JQ348502 \\
\hline 39 & $\begin{array}{l}\text { DNA/ } \\
\text { allozymes }\end{array}$ & 39.6667 & -9.000 & Pataias & Portugal & B. b. spinosus & Iberian & & JQ348597 & JQ348740 & \\
\hline 40 & DNA & 43.5248 & 5.5470 & Le Tholonet & France & B. b. spinosus & Iberian & & JQ348553 & JQ348696 & JQ348480 \\
\hline 41 & DNA & 43.0462 & -1.0733 & Larrau & France & B. b. bufo & Iberian & & JQ348682 & JQ348827 & JQ348498 \\
\hline 42 & DNA & 40.2841 & -5.2497 & Gredos 1 & Spain & B. b. gredosicola & Iberian & & JQ348592 & JQ348735 & JQ348512 \\
\hline 43 & DNA & 40.2841 & -5.2497 & Gredos 2 & Spain & B. b. gredosicola & Iberian & & JQ348593 & JQ348736 & JQ348513 \\
\hline 44 & DNA & 40.2841 & -5.2497 & Gredos 3 & Spain & B. b. gredosicola & Iberian & & JQ348569 & JQ348712 & JQ348511 \\
\hline 45 & $\begin{array}{l}\text { DNA/ } \\
\text { allozymes }\end{array}$ & 43.5547 & 2.7941 & $\begin{array}{l}\text { Lac du Saut de } \\
\text { Vésoles }\end{array}$ & France & B. b. spinosus & Iberian & & JQ348548 & JQ348691 & JQ348482 \\
\hline 46 & DNA & 40.8640 & -3.6156 & La Cabrera & Spain & B. b. spinosus & Iberian & & JQ348584 & JQ348727 & JQ348494 \\
\hline 47 & DNA & 36.5444 & -5.6616 & $\begin{array}{l}24 \mathrm{~km} \text { NE of } \\
\text { medina-Sidonia }\end{array}$ & Spain & B. b. spinosus & Iberian & & JQ348566 & JQ348709 & JQ348508 \\
\hline 48 & DNA & 43.0556 & -5.3261 & Isoba & Spain & B. b. bufo & Iberian & & JQ348586 & JQ348729 & JQ348495 \\
\hline 49 & DNA & 42.8816 & -0.7153 & Lac d'Ansabère & France & ambiguous & Iberian & & JQ348574 & JQ348717 & JQ348521 \\
\hline 50 & DNA & 41.7867 & 1.2908 & Guissona & Spain & B. b. spinosus & Iberian & & JQ348588 & JQ348731 & JQ348489 \\
\hline 51 & DNA & 37.6568 & -5.5224 & Lora del Rio & Spain & B. b. spinosus & Iberian & & JQ348578 & JQ348721 & JQ348510 \\
\hline 52 & DNA & 36.2767 & -6.0884 & $\begin{array}{l}\text { Conil de la } \\
\text { Frontera }\end{array}$ & Spain & B. b. spinosus & Iberian & & JQ348587 & JQ348730 & JQ348519 \\
\hline 53 & DNA & 43.9638 & 3.3232 & Combe-Redonde & France & B. b. spinosus & Iberian & & JQ348554 & JQ348697 & \\
\hline 54 & DNA & 42.4728 & -7.9853 & $\begin{array}{l}\text { San Cristovo de } \\
\text { Cea }\end{array}$ & Spain & ambiguous & Iberian & & JQ348551 & JQ348694 & JQ348476 \\
\hline 55 & DNA & 36.9612 & -3.3586 & Capileira & Spain & B. b. spinosus & Iberian & & JQ348594 & JQ348737 & JQ348509 \\
\hline 56 & DNA & 42.3719 & 2.9221 & Capmany & Spain & B. b. spinosus & Iberian & & JQ348576 & JQ348719 & JQ348484 \\
\hline
\end{tabular}


vicariance (Savage, 1973; Borkin, 1984; Voelker, 1999). For amphibians, Savage (1973) and Borkin (1984) hypothesized that the progressive aridification of Central Asia coupled with global cooling trends during the Miocene (23-5.3 Ma) forced the amphibian faunas to retract their ranges to the South, forming isolates at both sides of the great Central Asian Deserts.

After the above-mentioned splits between Eastern and Western domains, each lineage diversified regionally throughout the rest of the Neogene. However, the major causes of these cladogenetic events in most cases are debated. In the Western Palearctic, the classic "glacial refugia" theory attempts to explain most of these cladogenetic events as a consequence of shifts in the distributional ranges towards the South during the glacial maxima, leading to subsequent allopatric isolation and genetic differentiation in the Mediterranean Peninsulas (Hewitt, 2000). The existence of species or subspecies broadly dividing into Eastern and Western groups backed this theory (e. g. Pelobates cultripes/Pelobates fuscus), suggesting that both groups were derived from refugia located in different Mediterranean Peninsulas (mainly Iberian Peninsula, Italian Peninsula and the Balkans) (Llorente et al., 1995). However, dating estimates revealed that although some of the splits were associated with the glacial cycles, this was not a general rule and many splits could be firmly placed in Pre-Pleistocene times (Seddon et al., 2001; Babik et al., 2007). Therefore, the role of Pleistocene glacial cycles shifted from being one of the most important processes for explaining the current diversity of species in the Palearctic to a more labile process with different degrees of relevance depending on the particular organism and the temporal scale considered (Klicka and Zink, 1997; Soria-Carrasco and Castresana, 2011). A more modern view is that the phylogeographic structure of most Paleartic groups is actually a combination of deep splits during the Miocene or Pliocene, followed by a re-structuring caused by fluctuations in population sizes experienced during the Quaternary (e.g. Paulo et al., 2001; Mattoccia et al., 2005; Nascetti et al., 2005; Ursenbacher et al., 2008). Nevertheless, in most cases the historical causes of these deep splits usually remain elusive.

Amphibians constitute a very good model to explore the historical aspects of species distributions due to their low dispersal capacity and retention of a strong phylogeographic signal. Moreover, they are very sensitive to climatic changes, which make them optimal organisms for discriminating the effects of glacial cycles and other environmental changes upon their genetic structure and biogeographic patterns (Zeisset and Beebee, 2008). The European common toad belongs to the genus Bufo (sensu stricto), a pan-Eurasiatic group comprising two species complexes. Eastern Eurasia contains the greatest species richness of the genus, with 13-14 recognized species distributed across Central and Eastern China, Northern Vietnam, Korea, far Eastern Russia, and Japan (here and after the Bufo gargarizans species complex) (Frost, 2011; see also Zhan and $\mathrm{Fu}, 2011$ ).

The second complex occurs in the Western Palearctic, and only two or three valid species are currently recognized (here and after the Bufo bufo species complex) (Litvinchuk et al., 2008; Frost, 2011): the Eichwald toad (Bufo eichwaldi Litvinchuk et al., 2008), restricted to the Talysh mountains of the Southeastern Caucasus; the Caucasian toad (Bufo verrucosissimus (Pallas, 1814), not recognized by e.g. Crochet and Dubois, 2004), which inhabits the Caucasus and Anatolia; and the European common toad (Bufo bufo (Linnaeus, 1758)), the Palearctic anuran with the largest distributional range, spanning from North Africa to the Polar circle and from the Western Iberian Peninsula to the Baikal Lake in Siberia (Lizana, 2002). Despite this huge distributional range, according to Mertens and Wermuth (1960), the European common toad is a single species with three subspecies: (1) the nominate subspecies Bufo bufo bufo, the Eurosiberian form, distributed across Northern and Central Europe, Western Siberia, the British Islands and the Eurosiberian enclaves of the Mediterranean peninsulas, (2) Bufo bufo spinosus Mertens, 1925, considered the Mediterranean counterpart of the nominal subspecies, occupying the Mediterranean margins of Europe, North Africa and most parts of Western and Central France (Geniez and Cheylan, 2005, in press), and (3) Bufo bufo gredosicola Müller \& Hellmich, 1925, with a very limited distributional range restricted to the highest prairies and lakes of the Sierra de Gredos, in Central Iberian Peninsula.

Since the European common toad and its closest relatives present a disjunct distribution across Eurasia (Lizana, 2002), and also show regional structure in the Western Palearctic, they provide an interesting opportunity to examine the importance of the Central Asian Deserts as the vicariant event that separated Eastern and Western species complexes, and secondly to assess the relative contribution of both glacial and preglacial events in the regional structure of the Western Palearctic.

The aim of the present study is to combine data from molecular phylogenies, multiple correspondence analyses of allozyme data and species distribution models, to unravel the historical processes that have contributed to shaping the biogeography and cladogenesis of the most abundant and widely distributed amphibian genus in the Palearctic.

\section{Methods}

\subsection{Taxon sampling, DNA extraction, amplification and sequencing}

A total of 151 specimens were included in the mitochondrial DNA study, covering the entire distribution range of the species complex in the Western Palearctic (Table 1 and Fig. 1). Of these, 147 are members of the Bufo bufo species complex, with four specimens obtained from GenBank (Benson et al., 2008). The remaining four specimens belong to the Bufo gargarizans species complex and were used as outgroups (all obtained from GenBank). A list of all the samples used in the present work with their extraction codes, voucher references, corresponding localities and GenBank accession numbers can be found in Table 1. Genomic DNA was extracted from ethanol-preserved tissue samples using the Qiagen DNeasy Blood \& Tissue Kit. A total of 1988 bp of mitochondrial DNA were sequenced for most of the specimens (5.8\% of missing data), encompassing fragments of three genes: tRNAval (48 bp), 16SrRNA (1386 bp) and ND1 (554 bp). Already published primers for the amplification and sequencing of the mitochondrial gene fragments included in the present study as well as PCR conditions used are given in detail in Biju and Bossuyt (2003) and Roelants and Bossuyt (2005). All amplified fragments were sequenced for both strands. Contigs were assembled in Geneious v. 5.3.6 (Biomatters Ltd.).

\subsection{Phylogenetic analyses of mitochondrial DNA}

The sequences obtained were aligned using the online version of MAFFT 6.240 (Katoh et al., 2002) (http://align.bmr.kyushuu.ac.jp/mafft/online/server/), following a FFT-NS-i strategy (slow, iterative refinement method) with the rest of the settings left by default (scoring matrix 200PAM $(k=2)$, gap opening penalty $=1.53$ ). The gaps generated by the process of alignment were considered missing data in all the following analyses.

Two methods of phylogenetic analysis, namely maximum likelihood (ML) and Bayesian analysis (BI), were employed and their results compared. The ML analysis was performed using RaxML 7.0.4 (Stamatakis, 2006) with the dataset split in two partitions: one partition including the RNA-coding genes and the other including the protein-coding gene (ND1). JModeltest (Posada, 2008) was used to select the most appropriate model of sequence evolution 


\title{
Molecular phylogenetics and historical biogeography of the west-palearctic common toads (Bufo bufo species complex)
}

\author{
J. Garcia-Porta ${ }^{\text {a }}$, S.N. Litvinchuk ${ }^{\text {b }}$, P.A. Crochet $^{c}$, A. Romano ${ }^{\text {d }}$, P.H. Geniez ${ }^{\text {c }}$, M. Lo-Valvo ${ }^{\text {, }}$ \\ P. Lymberakis ${ }^{f}$, S. Carranza ${ }^{\text {a,* }}$ \\ ${ }^{a}$ Institute of Evolutionary Biology (CSIC-UPF), Passeig Marítim de la Barceloneta, 37-49, 08003 Barcelona, Spain \\ b Institute of Cytology, Russian Academy of Sciences, Tikhoretsky pr. 4, 194064 St. Petersburg, Russia

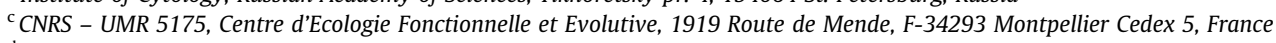 \\ 'Dipartimento di Biologia, Università di Roma “Tor Vergata", Via della Ricerca Scientifica, I-00133 Rome, Italy \\ e Dipartimento di Biologia ambientale e biodiversità, Via Archirafi 18, I-90123 Palermo, Italy \\ ${ }^{\mathrm{f}}$ Natural History Museum of Crete, University of Crete, Knosou Av., PO Box 2208, 71409 Irakleio, Greece
}

\section{A R T I C L E I N F O}

\section{Article history:}

Received 27 May 2011

Revised 18 December 2011

Accepted 20 December 2011

Available online 30 December 2011

\section{Keywords:}

Amphibian

Phylogeny

Biogeography

Deserts

Diversification

Pleistocene glaciations

\begin{abstract}
A B S T R A C T
In most pan-Eurasiatic species complexes, two phenomena have been traditionally considered key processes of their cladogenesis and biogeography. First, it is hypothesized that the origin and development of the Central Asian Deserts generated a biogeographic barrier that fragmented past continuous distributions in Eastern and Western domains. Second, Pleistocene glaciations have been proposed as the main process driving the regional diversification within each of these domains. The European common toad and its closest relatives provide an interesting opportunity to examine the relative contributions of these paleogeographic and paleoclimatic events to the phylogeny and biogeography of a widespread Eurasiatic group. We investigate this issue by applying a multiproxy approach combining information from molecular phylogenies, a multiple correspondence analysis of allozyme data and species distribution models. Our study includes 304 specimens from 164 populations, covering most of the distributional range of the Bufo bufo species complex in the Western Palearctic. The phylogenies (ML and Bayesian analyses) were based on a total of $1988 \mathrm{bp}$ of mitochondrial DNA encompassing three genes (tRNAval, 16S and ND1). A dataset with 173 species of the family Bufonidae was assembled to estimate the separation of the two pan-Eurasiatic species complexes of Bufo and to date the main biogeographic events within the Bufo bufo species complex. The allozyme study included sixteen protein systems, corresponding to 21 presumptive loci. Finally, the distribution models were based on maximum entropy. Our distribution models show that Eastern and Western species complexes are greatly isolated by the Central Asian Deserts, and our dating estimates place this divergence during the Middle Miocene, a moment in which different sources of evidence document a major upturn of the aridification rate of Central Asia. This climate-driven process likely separated the Eastern and Western species. At the level of the Western Palearctic, our dating estimates place most of the deepest phylogenetic structure before the Pleistocene, indicating that Pleistocene glaciations did not have a major role in splitting the major lineages. At a shallow level, the glacial dynamics contributed unevenly to the genetic structuring of populations, with a strong influence in the European-Caucasian populations, and a more relaxed effect in the Iberian populations.
\end{abstract}

(ㄷ) 2011 Elsevier Inc. All rights reserved.

\section{Introduction}

Throughout the Neogene (23-2.6 Ma), the Palearctic region has experienced several climatic and physiographic changes that have modulated the diversification of its biotas and shaped their distributions. This is particularly true for pan-Eurasiatic groups with distributions extending from the Western to the Eastern Palearctic; several paleoclimatic or paleogeographic events ranging from a re-

\footnotetext{
* Corresponding author. Fax: +34 932309555.

E-mail address: salvador.carranza@ibe.upf-csic.es (S. Carranza).
}

gional to a global scale (Blondel and Aronson, 1999; Azanza et al., 2000; Fortelius et al., 2002; Melville et al., 2009) have likely structured these populations. Singularly, the rise of the Himalayas is one of the most important landmarks for understanding the distribution patterns in the Palearctic. This process, initiated 45-55 Ma, is considered the continents' largest perturbation to atmospheric circulation, ultimately originating the Central Asian Deserts and the monsoon-like climate in Eastern Asia (Molnar et al., 2010). Several cases of sister-species complexes at both sides of the deserts have led to the hypothesis that the origin of the Central Asian Deserts separated many Eastern and Western species complexes by 